\title{
Groundwater potentiality and evaluation in the Egyptian Nile Valley: case study from Assiut Governorate using hydrochemical, bacteriological approach, and GIS techniques
}

\author{
Hanaa A. Megahed ${ }^{1 *}$ and Abd El-Hay A. Farrag ${ }^{2}$
}

\begin{abstract}
Background: The expected deficit of the Egyptian share of the River Nile budget with the construction of the Renaissance Dam in Ethiopia necessitates a proper utilization of the water resources in the Nile Valley. The present study aims at characterizing the chemical and bacteriological compositions of the groundwater in the Quaternary and Eocene fractured limestone aquifers in Assuit Governorate as a suggested scheme for the groundwater quality evaluation in the Egyptian River Nile basin.

Results: We analyzed 92 samples collected from shallow boreholes within $15 \mathrm{~km}$ on both sides of the River Nile for major, minor, and trace ions and compared the results to the national and international standards for drinking water. Some chemical data were collected from Assiut Drinking Water Station while some other samples were analyzed chemically and bacteriological in the Laboratories of Science and agriculture faculties and the laboratories of Assiut Drinking \& sanitation Company. The groundwater composition is seasonally variable depending on the variation in the local surface water (level composition). The results of bacteriological examination show that the highest most probable number of total coliform was found $5.9 \mathrm{MPN} / 100 \mathrm{ml}$ and the minimum value of MPN of total coliform was found 1.1 MPN/100 ml. Groundwater potentiality and evaluation for drinking and domestic uses depend on several parameters which must be taken into consideration.

Conclusions: The current research concluded that the GIS-based water potentiality spatial model (WPSM) indicated that the northwest part and southeast part represented the highest and lowest potentiality respectively for drinking water purposes. The suggested scheme in this study could be a valid tool to evaluate the water quality in the River Nile basin and similar settings worldwide.
\end{abstract}

Keywords: Hydrochemical analysis, Bacteriological analysis, River Nile, Groundwater quality, GIS

\footnotetext{
*Correspondence: hanaanarss@yahoo.com

${ }^{1}$ National Authority for Remote Sensing and Space Sciences (NARSS), Cairo,

Egypt

Full list of author information is available at the end of the article
} 


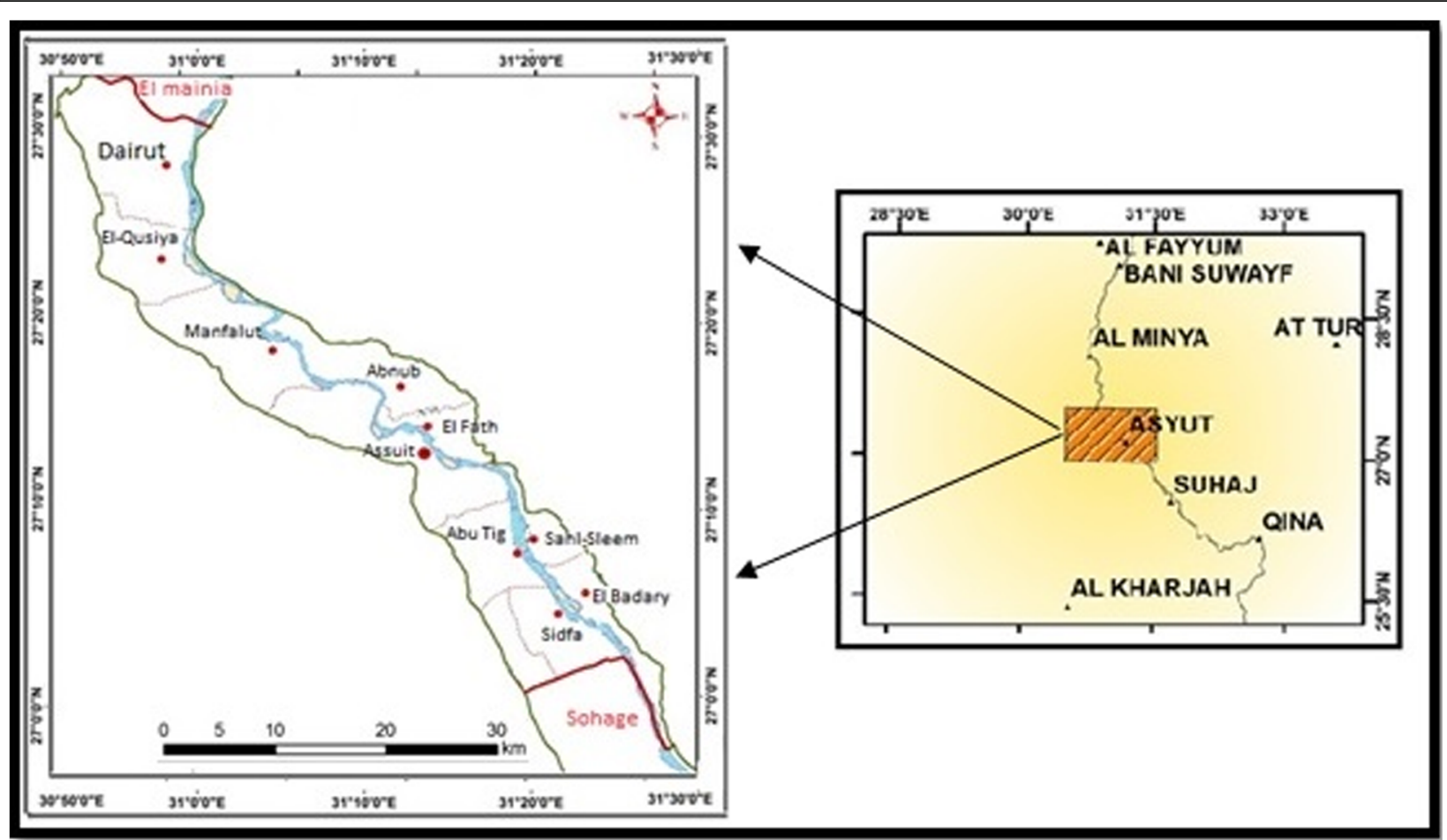

Fig. 1 Location map of Assiut Governorate

\section{Background}

Groundwater is an important source of water supply in many parts of the world in particular in desert environments such as in Egypt. The expected storage in the Nile water in the near future, as upstream countries proceed with building dams on the main course of the river, encourage the government and research institutions to look for the optimum solutions for sustainable use of drinking water. The quality of portable groundwater in the Nile Valley such

Table 1 Some climatic data averages (Assiut Meteorological Station. 2010-2017)

\begin{tabular}{|c|c|c|c|c|c|c|}
\hline \multicolumn{7}{|c|}{ Assiut Meteorological Station (2010-2016) } \\
\hline \multirow[t]{2}{*}{ Month } & \multicolumn{2}{|c|}{ Temperature } & \multirow{2}{*}{$\begin{array}{l}\text { Wind } \\
\text { velocity } \\
\mathrm{m} / \mathrm{s}\end{array}$} & \multirow{2}{*}{$\begin{array}{l}\text { Evaporation } \\
\text { (mm/day) }\end{array}$} & \multicolumn{2}{|l|}{ Rainfall } \\
\hline & $\begin{array}{l}\text { Min. } \\
\text { temp. } \\
{ }^{\circ} \mathrm{C}\end{array}$ & $\begin{array}{l}\text { Max. } \\
\text { temp. } \\
{ }^{\circ} \mathrm{C}\end{array}$ & & & Rainfall (mm/month) & Max rainfall in 1 day $/ \mathrm{mm}$ \\
\hline January & 5.5 & 18 & 5.6 & 6.39 & 0.4 & 0 \\
\hline February & 6.5 & 21.6 & 6.4 & 8.52 & 0.18 & 2.5 \\
\hline March & 10.1 & 25.6 & 8.6 & 11.83 & 0.07 & 1 \\
\hline April & 14.9 & 31.6 & 8 & 16.14 & 0.07 & 2.5 \\
\hline May & 18.9 & 35.3 & 6.4 & 19.92 & 0.1 & 0 \\
\hline June & 21.4 & 37.4 & 7.2 & 21.84 & 0 & 0 \\
\hline July & 22.2 & 36.8 & 7 & 19.47 & 0 & 0 \\
\hline August & 21.9 & 36.3 & 6 & 17.74 & 0 & 0 \\
\hline September & 19.6 & 34.2 & 7.2 & 16.01 & 0 & 0 \\
\hline October & 16.8 & 31.3 & 5.6 & 12.44 & 0.01 & 0 \\
\hline November & 11.4 & 25.5 & 4.4 & 8.23 & 0.01 & 0 \\
\hline December & 7.2 & 21 & 4.4 & 5.99 & 0.12 & 0.1 \\
\hline
\end{tabular}


as in Assuit Governorate is currently threatened by the chemical and microbiological contamination. Domestic sewage water from septic tanks is one of the main sources contributing to the groundwater pollution in these areas. For example, infiltration of surface water carrying animal waste or sewage to the water horizons in the Central part of the Nile Valley lead to gastrointestinal illnesses, as fecal material may contain various pathogenic microbes (Schijven et al. 2010). According to the World Health Organization, up to $50 \%$ of the population in developing countries suffers from health problems associated with lack of clean drinking water (World Health Organization 1992). The quality of groundwater in terms of microbiological and chemical contents is crucial to determining its suitability for drinking use. Detection of bacterial indicators in water samples is an evidence for the presence of pathogenic organisms that are likely the source of water-related fatal diseases (Macler and Merkel 2000). In this study, we aim at providing an integrated hydrochemical and bacteriological analyses in a geographic information system (GIS) environment to evaluate the water quality in the central part of the Nile Valley, Egypt. We use the analysis of major, minor and trace ions, and concentration of coliform bacteria in the study area; we then use GIS interpolation methods to represent the spatial distribution of the analysis results. We compare the results relative to the international and national standards for drinking water purposes and finally we develop a GIS-based water potentiality spatial model to assess the various classes of water quality in the study area.

\section{Location and description of the study area}

Assiut Governorate is located between latitudes $26^{\circ}$ $50^{\prime}$ and $27^{\circ} 40^{\prime}$ North and longitudes $30^{\circ} 40^{\prime}$ and $31^{\circ} 32^{\prime} 13.5^{\prime \prime}$ East and bordering the River Nile on both its eastern and western sides (Fig. 1).

\section{Climate}

Assiut Governorate belongs to the arid belt of Egypt which is characterized by long and hot summer, cold winter, low rainfall, and high evaporation rates. According to Assiut Meteorological Station, the average daily air temperature is about $22.7{ }^{\circ} \mathrm{C}$ in the area. The summer seasons are dry and very hot with mean temperature reaching up to $37{ }^{\circ} \mathrm{C}$. December to February periods is the coldest months where the mean temperature falls to $18{ }^{\circ} \mathrm{C}$ (Table 1 and Fig. 2).

\section{Geological and hydrogeological situation}

Many studies were carried out concerning the geological and hydrogeological situations concerning

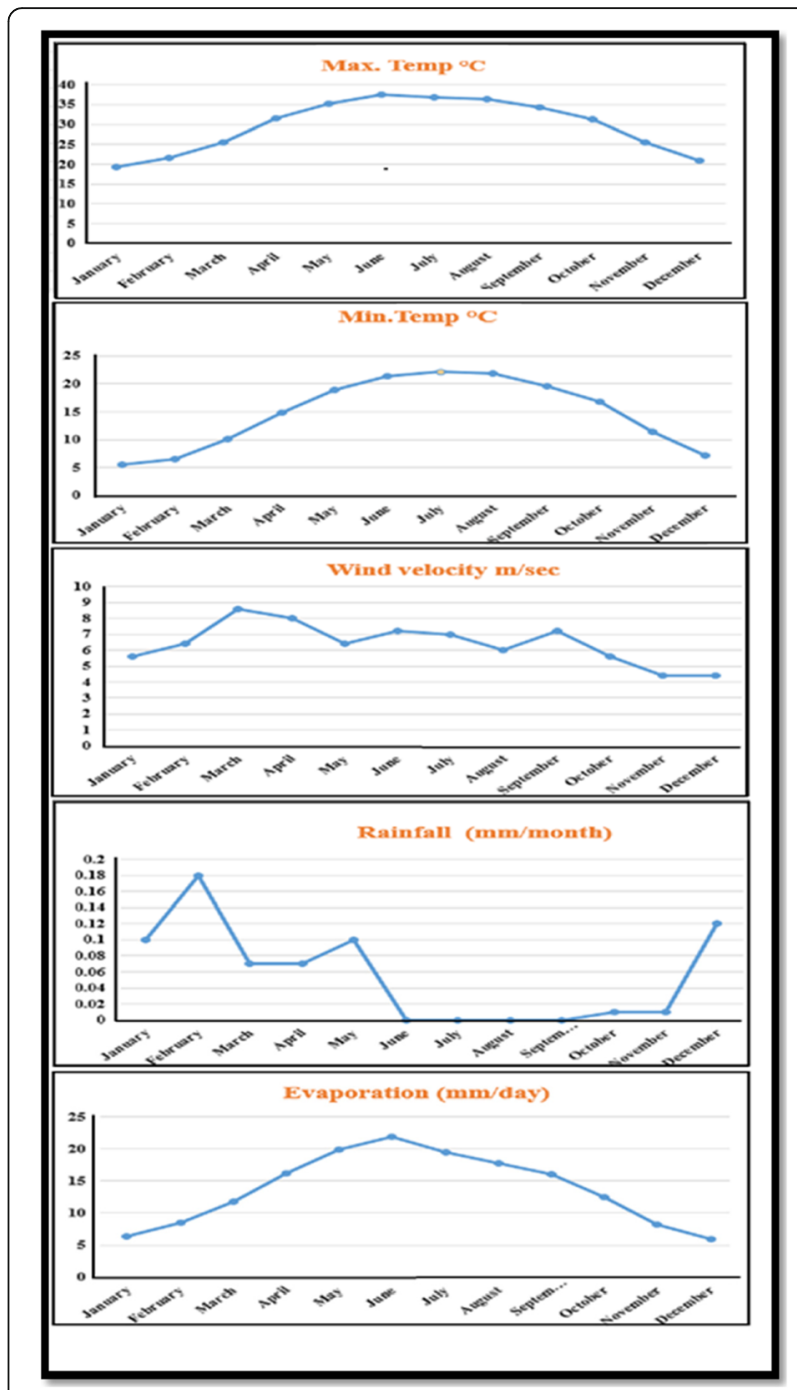

Fig. 2 Climatic data diagrams of the study area

Assiut Governorate. A brief idea about these studies is given in the following part. The Nile Valley in the Assuit area is bounded from the east and the west by the Eocene Limestone plateau. The cultivated area is wider in the western part than it is in the eastern one of the River Nile.

The area is generally slopes from the south to the north. The elevation of the western and eastern limestone plateaux ranges from +120 to $+220 \mathrm{~m}$, whereas the elevation of the floor of the studied area varies from +50 to $+60 \mathrm{~m}$ above sea level. It is underlain by clays, salt, sand, and gravel (Fig. 3).

Both the surface water and the groundwater are used for drinking and domestic uses. More than 700 groundwater wells were pumped for these purposes. These wells are located at 220 water pumping stations sites. Most of the used wells are penetrating 


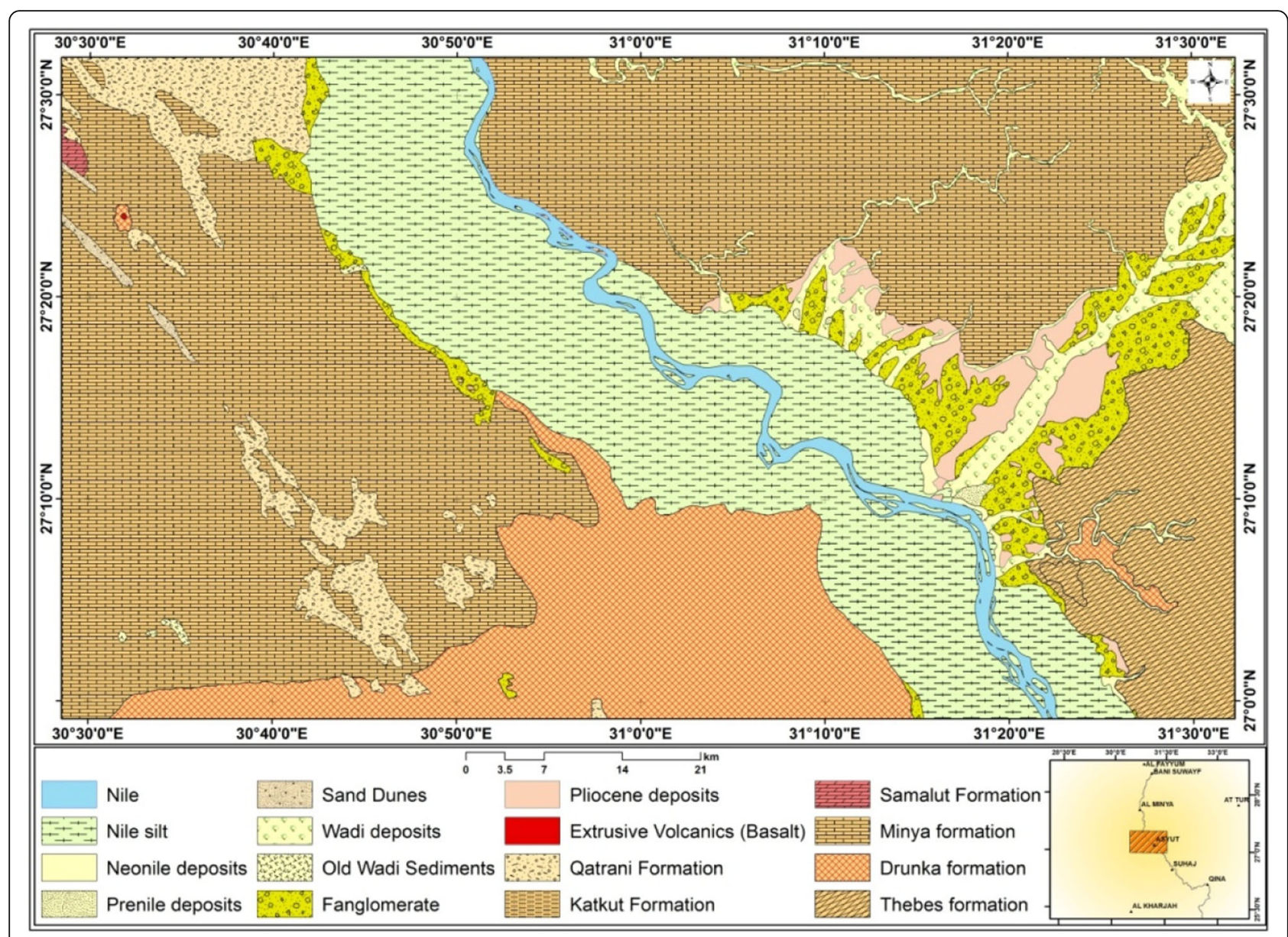

Fig. 3 Geological map of Assiut Governorate, Egypt (Mansour and Philobbos 1983)

the Quaternary water bearing sediments which are mainly recharged from the local surface water system. Other groundwater aquifers are present in and around the area. (Farrage 1982, 1991) concluded that the groundwater level of the aquifer descends gradually from the south to the north. $\mathrm{He}$ also concluded that the groundwater in the area is influenced by evaporation where the depth to the water table lies within the range of 3 to $4.5 \mathrm{~m}$, and the surface water plays an important role in recharging the groundwater. The surface water in the area is represented by the River Nile, El-Ibrahymia, El Sohagia, and Nag Hammadi Eastern canals. The Quaternary aquifer is the important aquifer in the area. It is formed from alluvial deposits of the Nile which consists of graded sand and gravel with thin interbeds of clay. The thickness of this aquifer as well as its width differs from one locality to another and the groundwater in this aquifer is present under semi-confined conditions (Farrage 1982). It is present under unconfined condition underneath the desert fringes where the Nile silt is absent. The sand and gravel of the
Pleistocene age cover the surface of the old alluvial plains bordering the valley which are subject to the new reclamation activities.

\section{Methods \\ Hydrochemical analysis}

Some field and laboratory measurements and analysis were carried out on 92 groundwater samples collected from many parts of the study area during February 2017 (Fig. 4). The samples were collected in polyethylene bottles $(1 \mathrm{~L})$ after $10 \mathrm{~min}$ of pumping to avoid any local contamination or evaporation. The physical and chemical parameters were estimated and measured including turbidity, total dissolved solids (TDS), hydrogen ion concentrations $(\mathrm{pH})$, and the concentrations of the major ions (sodium $\left(\mathrm{Na}^{+}\right)$, potassium $\left(\mathrm{K}^{+}\right)$, calcium $\left(\mathrm{Ca}^{2+}\right)$, magnesium $\left(\mathrm{Mg}^{2+}\right)$, sulfate $\left(\mathrm{SO}_{4}{ }^{2-}\right)$, bicarbonate $\left(\mathrm{HCO}_{3}{ }^{-}\right)$, and chloride $\left.\left(\mathrm{Cl}^{-}\right)\right)$ in addition to the trace ions (iron $\left(\mathrm{Fe}^{+}\right)$, manganese $\left(\mathrm{Mn}^{+}\right)$, and ammonia $\left(\mathrm{NH}_{3}{ }^{-}\right)$. The chemical analyses were carried out in the Laboratory of the Faculty of Agriculture, Assuit University. Electrical conductivity 


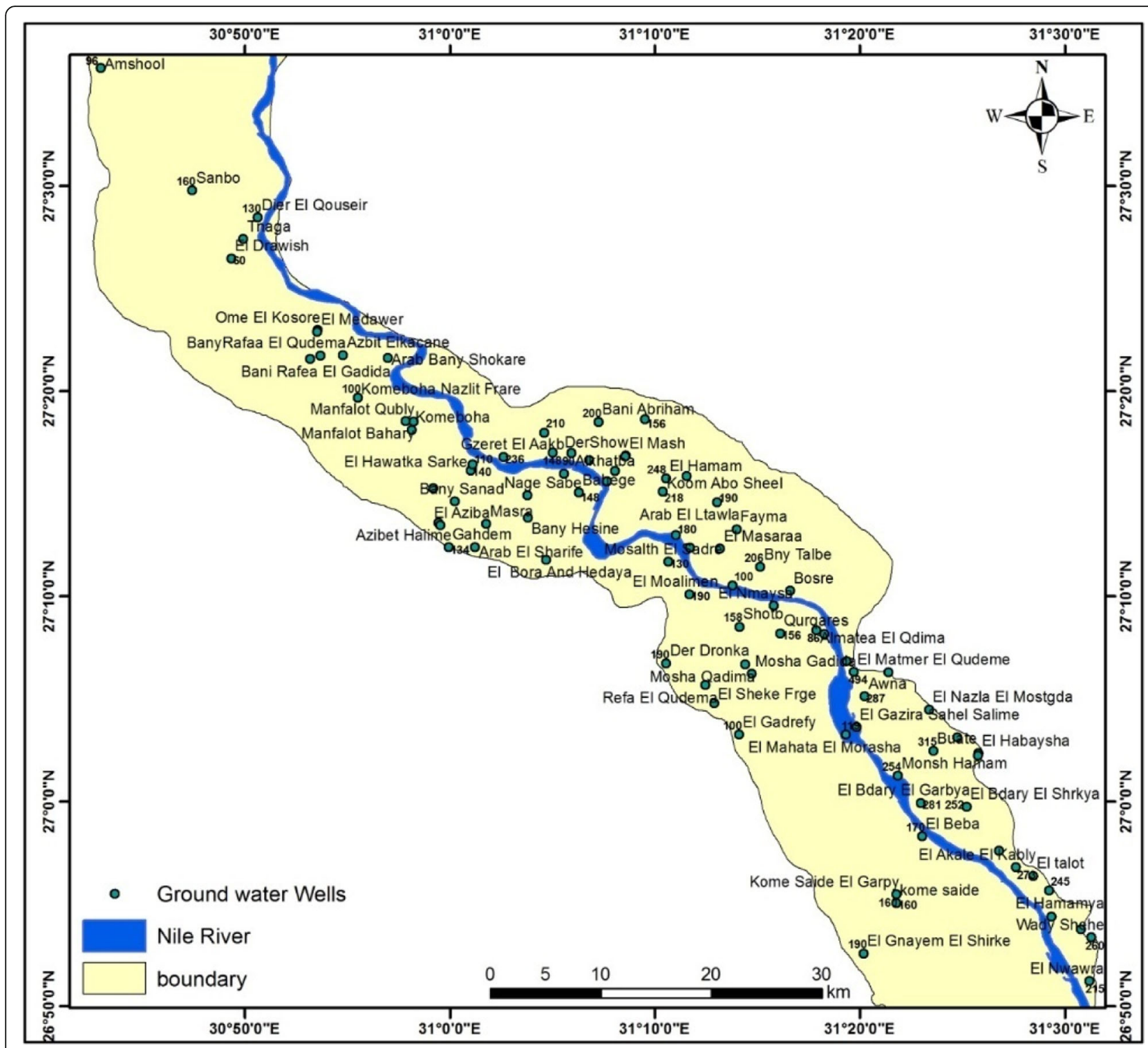

Fig. 4 Location map of groundwater wells, in Assiut Governorate

meter was used to estimate the total dissolved solids (TDS). $\mathrm{Ca}$ and $\mathrm{Mg}$ were determined using the titration with standard versenate (EDTA) solution, using Eriochrome Black $\mathrm{T}$ (EBT) as indicator. $\mathrm{Na}$ and $\mathrm{K}$ were determined using flamphotometry method. Carbonate and bicarbonate were determined by the titration with standard solution of hydrochloric acid. Chlorides were determined using standard solution of silver nitrate and sulfates were spectrophotometery measured using the turbidimetry method.

\section{Bacteriological analysis}

The water samples were collected using sterile $750 \mathrm{ml}$ containers. Before collection, the mouth and the outer parts of the borehole taps were sterilized with the direct flame of a cigarette lighter, and allowed to cool by running the water for about $1 \mathrm{~min}$. Thereafter, the sample bottles were rinsed with the sample water before filling them. The bottles were held at the bottom while filling, to avoid contamination from the hands or fingers. After recording the time of collection, the samples were labeled with code names before going to the laboratory for analysis.

In the lab, the samples were stored in cold room $\left(4{ }^{\circ} \mathrm{C}\right)$. The analysis was started without delay, based on the priority to analyze parameters as prescribed by APHA (American Public Health Association)-AWWA (American Water Works Association) 
Table 2 Standard most probable number (MPN) table for ten tubes

\begin{tabular}{ll}
\hline MPN per $100 \mathrm{ml}$ & Number of positive tubes \\
\hline$<1.1$ & 0 \\
1.1 & 1 \\
2.2 & 2 \\
3.2 & 3 \\
5.1 & 4 \\
6.9 & 5 \\
9.2 & 6 \\
12.0 & 7 \\
16 & 8 \\
23.0 & 9 \\
$>23$ & 10 \\
\hline
\end{tabular}

1994 methods. All the samples were analyzed for total coliform (TC) according to internationally accepted procedures and standard methods (APHAAWWA1994).

All media, chemicals, and reagents used were prepared according to manufacturer's specifications. The culture media used were sterilized using an autoclave at $121{ }^{\circ} \mathrm{C}$ for $15 \mathrm{~min}$, while Petri-dishes, pipettes, and other glass wares were sterilized in a hot air oven at $160{ }^{\circ} \mathrm{C}$ for $1 \mathrm{~h}$. The composition of the lauryl tryptose broth medium used was as follows. The procedure below is for estimation of coliforms by multiple-tube fermentation technique (MTF), also called most probable number (MPN) procedure in $96 \mathrm{~h}$, or less, in water samples on the basis of the production of gas and acid from fermentation of lactose. This procedure can be applied for non-potable water. The technique of enumerating
Table 3 Groundwater data compared with the maximum permissible concentration for drinking water according to the (WHO Guidelines 2004) and Egyptian limits (Egyptian Higher Committee for Water 2007)

\begin{tabular}{lllll}
\hline Constituent & Unit & $\begin{array}{l}\text { World Health } \\
\text { Organization } \\
(2004)\end{array}$ & $\begin{array}{l}\text { Egyptian } \\
\text { maximum } \\
\text { permissible } \\
\text { limits (EHCW } \\
2007\end{array}$ & $\begin{array}{l}\text { Average } \\
\text { concentration } \\
\text { range for the } \\
\text { studied water } \\
\text { samples }\end{array}$ \\
\hline $\mathrm{pH}$ & & $6.5-8.5$ & $6.5-8.5$ & 7.55 \\
$\mathrm{TDS}$ & ppm & 500 & 1000 & 950 \\
$\mathrm{Na}^{+}$ & ppm & 200 & 200 & 203.5 \\
$\mathrm{Ca}^{++}$ & ppm & 200 & - & 250 \\
$\mathrm{Mg}^{++}$ & ppm & 150 & - & 170 \\
$\mathrm{~K}^{+}$ & ppm & 30 & - & 9.25 \\
$\mathrm{Cl}^{-}$ & ppm & 250 & 250 & 300 \\
$\mathrm{SO}_{4}^{--}$ & ppm & 250 & - & 40 \\
$\mathrm{HCO}^{-}$ & ppm & 200 & 250 & 226 \\
$\mathrm{Fe}^{++}$ & ppm & 0.3 & 0.3 & 0.85 \\
$\mathrm{Mn}^{++}$ & ppm & 0.4 & 0.4 & 0.55 \\
\hline
\end{tabular}

coliforms by means of multiple tube fermentation (MTF) has been used for over 80 years as a water quality monitoring method. The method consists of inoculating a series of tubes with appropriate decimal dilutions of the water sample. Production of gas, acid formation, or abundant growth in the test tubes after $48 \mathrm{~h}$ of incubation at $35{ }^{\circ} \mathrm{C}$ constitutes a positive presumptive reaction.

Count the number of tubes that contain gas in the inner vial. Find the MPN of the sample (total coliform bacteria per $100 \mathrm{ml}$ sample) from the MPN table for ten tubes (Table 2). Both lactose and lauryl tryptose broths

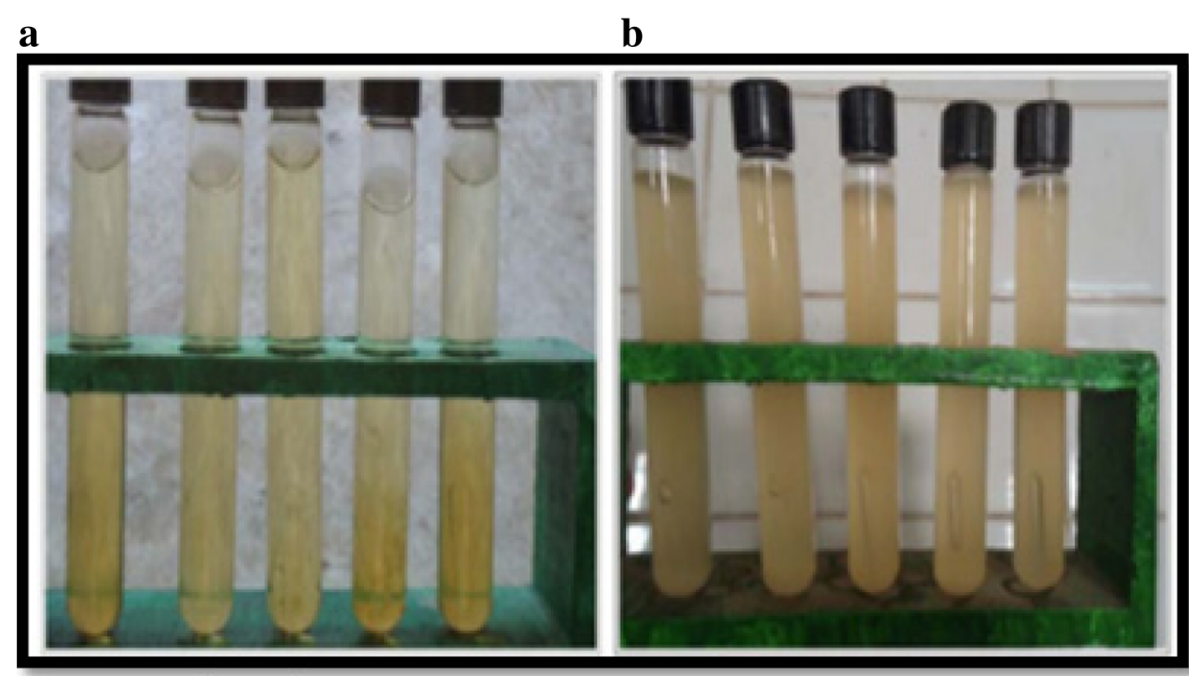

Fig. 5 a Negative lauryl tryptose broth tubes for coliform. b Positive presumptive test 
can be used as presumptive media, but Seidler et al. (1981) and Evans et al. (1981) have obtained interference, with high numbers of non-coliform bacteria, using lactose broth. All tubes with a positive presumptive reaction are subsequently subjected to a confirmation test. The formation of gas in a brilliant green lactose bile broth fermentation tube at any time within $48 \mathrm{~h}$ at $35^{\circ} \mathrm{C}$ constitutes a positive confirmation test (Fig. 5a, b).

\section{Results}

Water that can be used for domestic or drinking purposes should be physically colorless, odorless, transparent, and free from turbidity and microorganism. Chemically, the water should preferably be of low dissolved solid content, soft, and free from poisonous constituents.

Several parameters were established to determine the suitability of groundwater in the area for human drinking and domestic purposes. The fitness of this water was determined by comparing its chemical characteristics with the standards given by the Egyptian Higher Committee for Water (Egyptian Higher Committee for Water 2007) and World Health Organization (WHO Guidelines 2004). Other classification of the suitability of groundwater according to the TDS, major and trace elements are listed in (Table 3).

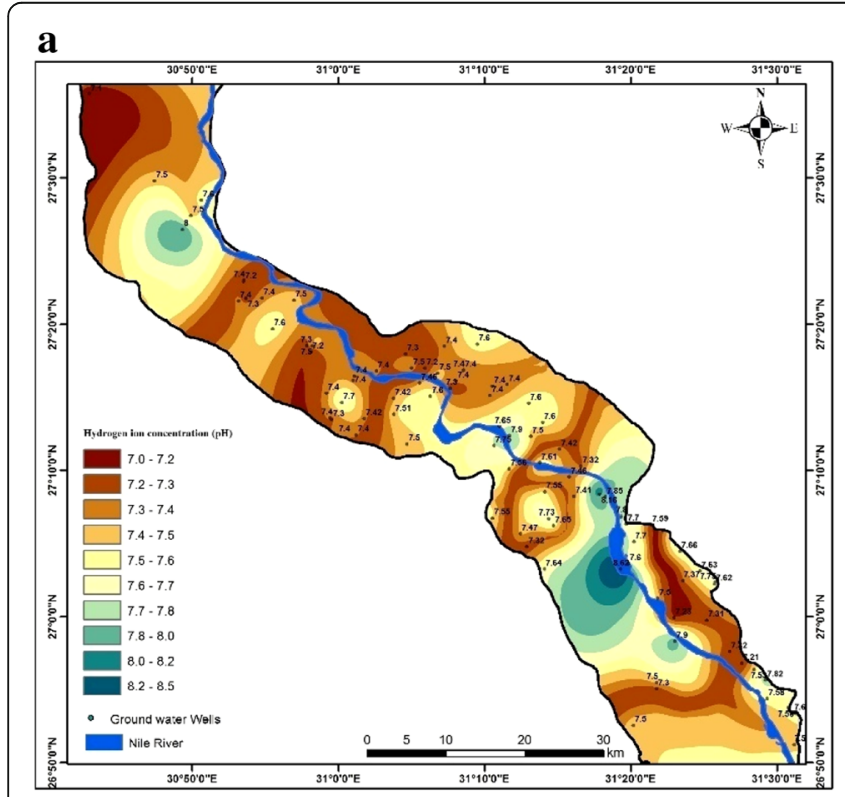

b

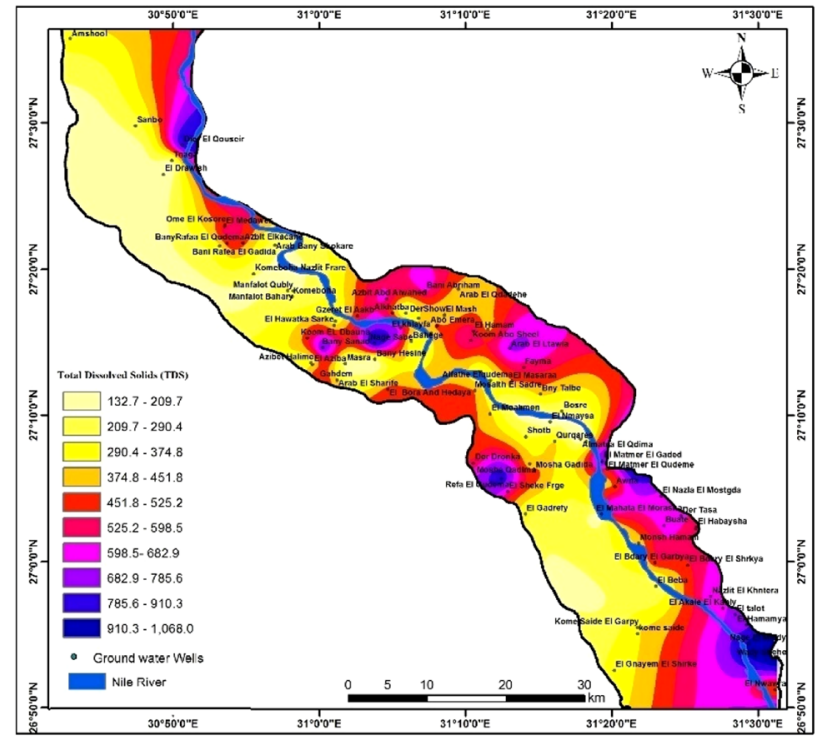

c

d
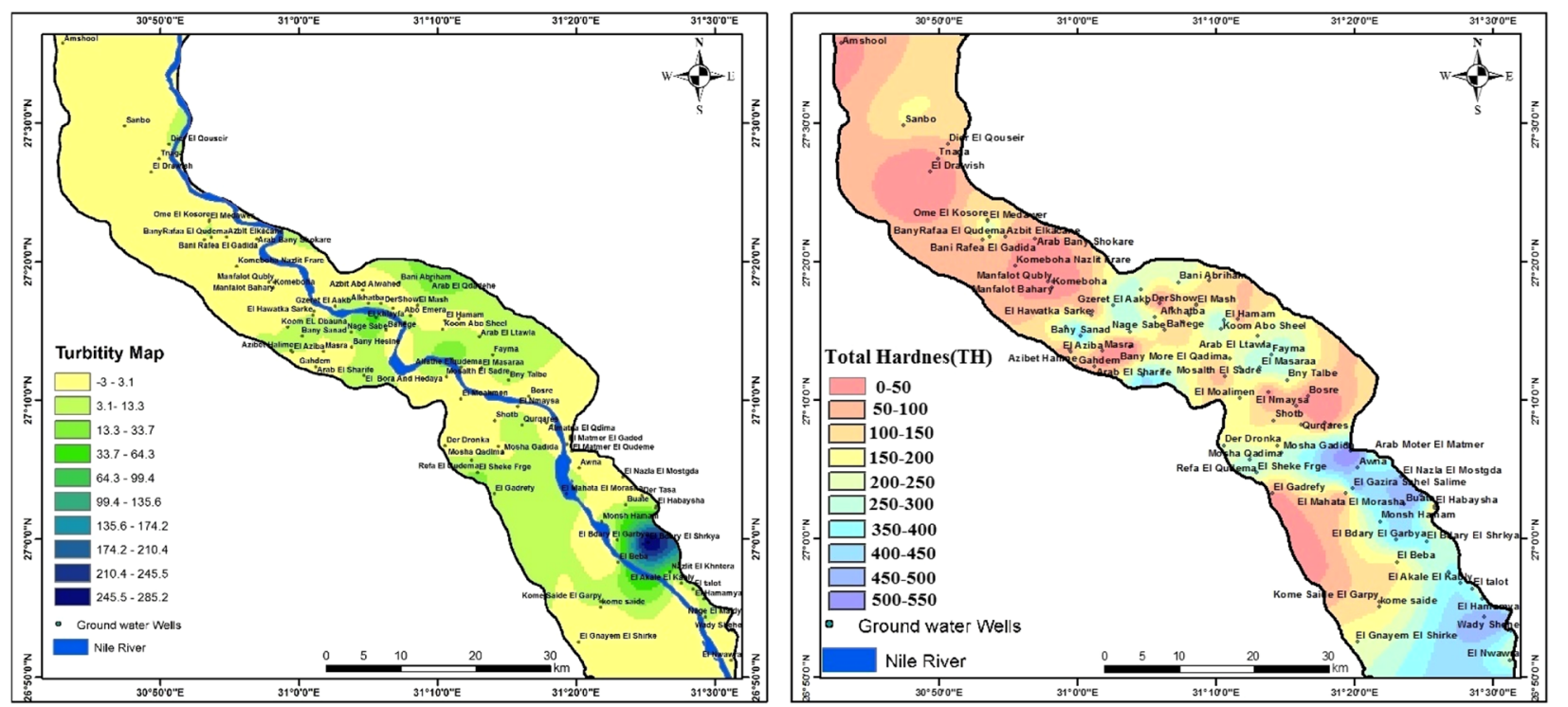

Fig. 6 Iso-concentration maps showing spatial variation in a $\mathrm{pH}, \mathbf{b} \mathrm{TDS}, \mathbf{c}$ turbidity, and $\mathbf{d} \mathrm{TH}$ in the study area 
Hydrogen ion concentration $(\mathrm{pH})$ is a measure of the acidity or alkalinity conditions of a solution. The $\mathrm{pH}$ values of the analyzed samples in the investigated area varied from 7 to 8.1. Accordingly, the groundwater in the studied area is classified as slightly acidic to light alkaline water (Fig. 6a). The accepted limits of $\mathrm{pH}$ value for drinking water ranging between 6.5 and 8.5 according to Egyptian standards while it is ranging between 6.5 and 8 according to WHO Standards, so the groundwater in the area has no problem regarding to its $\mathrm{pH}$ values (Fig. 7a).

The TDS are the measure of the total amount of minerals dissolved in water. It is a very useful parameter for evaluation water quality. Different methods are used for water classification according to its total dissolved salts content. Hem (1985) classified water according to TDS value into four classes: fresh, moderately saline, very saline, and brine water. The values of TDS in the groundwater in the area ranged from 200 to $1700 \mathrm{ppm}$. Figure $6 \mathrm{~b}$ and Table 4 show local increase in TDS value at the eastern parts of study area between Abnoub and Al Fath. A local TDS increase west of Manfalout and west of Assiut while it decreases near the River Nile and EL-Ibrahimiya Canal. It is observed that TDS values increase during January and February and decrease during July and
August. The accepted limit of TDS value for drinking water according to the Egyptian standards is $1000 \mathrm{ppm}$ while it is only $600 \mathrm{ppm}$ according to WHO Standards. Accordingly, most the groundwater in the area is acceptable for drinking purposes regarding to the TDS parameter except for the northwest Assiut and East Abnoub parts (Fig. 7b).

The turbidity values in groundwater in the area ranged from 0 to 10 NTU. Figure $6 \mathrm{c}$ and Table 4 show an increase in the turbidity values between Dayrout, Qusiya, and at the western parts of study area between Assiut and Abu Tieg. The accepted limit of turbidity value for drinking water according to Egyptian standards is 1 NTU, which mean that the groundwater in most of the area has no turbidity problem except for the mentioned localities.

The values of $\mathrm{TH}$ in groundwater in the area ranged from 150 to $550 \mathrm{ppm}$. Figure 6d shows an increasing in $\mathrm{TH}$ value between Manfalout and Assiut. TH decreases near the Nile River and EL-Ibrahimiya Canal. The accepted limit of $\mathrm{TH}$ value for drinking water according to Egyptian standards is $500 \mathrm{ppm}$ while it is 200 ppm according to WHO Standards. Accordingly, the groundwater is accepted for drinking purposes regarding to Egyptian limits.

Calcium content in groundwater ranged from 100 to $400 \mathrm{ppm}$. Figure $8 \mathrm{a}$ and Table 4 show general

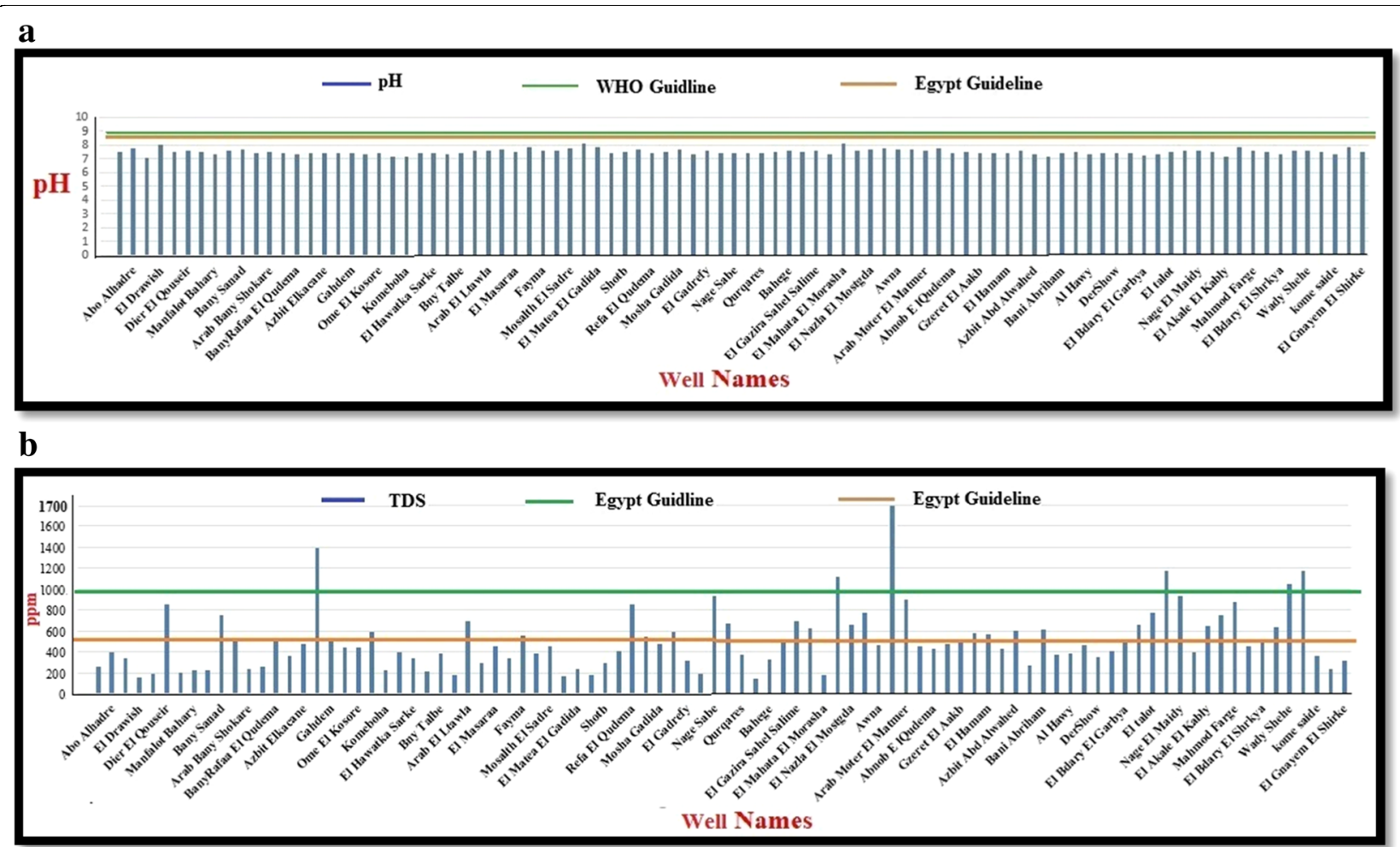

Fig. 7 a Hydrogen ion concentration and $\mathbf{b}$ total dissolved solids concentration in the groundwater samples compared with WHO Guidelines (2004) and Egyptian Higher Committee for Water (2007) guidelines for drinking water 
Table 4 Results of chemical analyses of studied groundwater samples in Assuit Governorate

\begin{tabular}{|c|c|c|c|c|c|c|c|c|c|c|c|c|c|c|}
\hline \multirow[t]{2}{*}{ N } & \multirow[t]{2}{*}{ Location } & \multirow[t]{2}{*}{$\mathrm{pH}$} & \multirow[t]{2}{*}{ Turb } & \multirow[t]{2}{*}{ TDS } & \multicolumn{4}{|c|}{ Major cation } & \multicolumn{3}{|c|}{ Major anion } & \multicolumn{3}{|c|}{ Trace Elements } \\
\hline & & & & & $\overline{\mathrm{Na}^{+}}$ & $\mathrm{K}^{+}$ & $\mathrm{Ca}^{+2}$ & $\mathrm{Mg}^{+}$ & $\overline{\mathrm{SO}_{4}{ }^{-2}}$ & $\mathrm{Cl}-$ & $\overline{\mathrm{HCO}_{3}}$ & $\overline{\mathrm{Fe}+}$ & $\mathrm{Mn+}$ & $\mathrm{NH}_{3}{ }^{-}$ \\
\hline 1 & Sanbo & 7.50 & 0.70 & 260 & 150 & 4.69 & 160.00 & 110.00 & 45 & 50 & 170 & 0.50 & 0.40 & 0.10 \\
\hline 2 & Abo Alhadre & 7.80 & 0.60 & 400 & 146 & 3.91 & 136 & 44.00 & 32 & 442 & 120 & 0.30 & 0.10 & 0.20 \\
\hline 3 & Amshool & 7.10 & 1.60 & 340 & 100 & 4.52 & 196 & 244.00 & 20 & 325 & 110 & 0.40 & 0.20 & 0.10 \\
\hline 4 & El Drawish & 8.00 & 0.50 & 156 & 70 & 29.33 & 160 & 66.00 & 15 & 114 & 58 & 0.50 & 0.20 & 0.10 \\
\hline 5 & Tnaga & 7.50 & 1.50 & 185 & 110 & 4.60 & 100 & 140.00 & 30 & 225 & 90 & 0.30 & 0.40 & 0.20 \\
\hline 6 & Dier El Qouseir & 7.60 & 3.20 & 855 & 142 & 3.91 & 130 & 75.00 & 35 & 336 & 120 & 0.50 & 0.50 & 0.30 \\
\hline 7 & Manfalot Qubly & 7.50 & 1.60 & 205 & 88 & 3.91 & 180 & 50.00 & 45 & 440 & 110 & 0.30 & 0.20 & 0.14 \\
\hline 8 & Manfalot Bahary & 7.30 & 0.98 & 223 & 90 & 2.74 & 188 & 44.00 & 45 & 540 & 130 & 0.40 & 0.10 & 0.15 \\
\hline 9 & Komeboha Nazlit Frare & 7.60 & 1.54 & 220 & 160 & 14.86 & 100 & 289 & 10 & 313 & 140 & 0.30 & 0.20 & 0.03 \\
\hline 10 & Bany Sanad & 7.70 & 5.30 & 751 & 225 & 11.73 & 286 & 100.00 & 40 & 335 & 320 & 0.40 & 0.30 & 0.28 \\
\hline 11 & Koom EL Dbauna & 7.40 & 3.10 & 513 & 210 & 7.04 & 224 & 106.00 & 50 & 525 & 256 & 0.30 & 0.40 & 0.18 \\
\hline 12 & Arab Bany Shokare & 7.50 & 2.70 & 234 & 108 & 6.26 & 106 & 46.00 & 15 & 110 & 140 & 0.20 & 0.20 & 1.50 \\
\hline 13 & Azibet Halime & 7.40 & 5.05 & 263 & 125 & 29.33 & 106 & 94.00 & 17 & 312 & 154 & 0.20 & 0.20 & 0.38 \\
\hline 14 & BanyRafaa El Qudema & 7.30 & 3.10 & 499 & 180 & 7.04 & 174 & 126.00 & 30 & 535 & 220 & 0.40 & 0.30 & 0.69 \\
\hline 15 & Bani Rafea El Gadida & 7.40 & 2.90 & 357 & 192 & 13.29 & 140 & 300 & 22 & 320 & 260 & 0.40 & 0.20 & 0.71 \\
\hline 16 & Azbit Elkacane & 7.40 & 1.40 & 480 & 130 & 8.99 & 124 & 164.00 & 20 & 524 & 280 & 0.30 & 0.20 & 0.54 \\
\hline 17 & Arab El Sharife & 7.40 & 0.51 & 1386 & 200 & 10.56 & 720 & 410.00 & 40 & 550 & 150 & 0.20 & 0.20 & 1.51 \\
\hline 18 & Gahdem & 7.40 & 0.79 & 511 & 134 & 8.21 & 134 & 96.00 & 65 & 270 & 248 & 0.30 & 0.20 & 1.69 \\
\hline 19 & El Aziba & 7.30 & 1.49 & 438 & 180 & 7.04 & 138 & 88.00 & 50 & 152 & 232 & 0.30 & 0.30 & 1.52 \\
\hline 20 & Ome El Kosore & 7.40 & 1.18 & 441 & 110 & 7.82 & 118 & 82.00 & 40 & 241 & 250 & 0.30 & 0.30 & 0.12 \\
\hline 21 & El Medawer & 7.20 & 2.69 & 592 & 230 & 7.82 & 232 & 108.00 & 40 & 245 & 310 & 0.20 & 0.40 & 0.55 \\
\hline 22 & Komeboha & 7.20 & 0.55 & 227 & 90 & 11.73 & 180 & 36.00 & 12 & 218 & 140 & 0.10 & 0.20 & 0.12 \\
\hline 23 & El Hawatka Garbe & 7.40 & 3.16 & 397 & 145 & 8.55 & 140 & 80.00 & 20 & 229 & 208 & 0.20 & 0.40 & 0.47 \\
\hline 24 & El Hawatka Sarke & 7.40 & 1.89 & 342 & 112 & 12.51 & 110 & 64.00 & 21 & 122 & 216 & 0.30 & 0.40 & 0.41 \\
\hline 25 & Bosre & 7.32 & 0.40 & 216 & 90 & 7.04 & 184 & 58 & 24 & 323 & 226 & 0.10 & 0.50 & 0.38 \\
\hline 26 & Bny Talbe & 7.42 & 4.12 & 381 & 205 & 8.21 & 206 & 60 & 47 & 150 & 390 & 0.45 & 0.15 & 0.06 \\
\hline 27 & Jazirat Elwasta & 7.61 & 1.23 & 182 & 109 & 8.21 & 100 & 200 & 20 & 322 & 210 & 0.18 & 0.30 & 0.16 \\
\hline 28 & Arab El Ltawla & 7.60 & 3.67 & 691 & 192 & 9.78 & 190 & 170.00 & 38 & 267 & 264 & 0.30 & 0.20 & 0.20 \\
\hline 29 & Bany More ElQadima & 7.65 & 28.10 & 294 & 180 & 10.90 & 180 & 68.00 & 50 & 149 & 260 & 1.50 & 0.30 & 0.56 \\
\hline 30 & El Masaraa & 7.50 & 1.45 & 448 & 155 & 5.08 & 228 & 152.00 & 30 & 235 & 506 & 0.20 & 0.20 & 0.50 \\
\hline 31 & Alfathe Elqudema & 7.90 & 1.04 & 338 & 280 & 15 & 208 & 132.00 & 15 & 217 & 352 & 0.15 & 0.10 & 0.60 \\
\hline 32 & Fayma & 7.60 & 10.20 & 552 & 233 & 10.95 & 240 & 140.00 & 12 & 120 & 448 & 1.00 & 0.10 & 0.30 \\
\hline 33 & El Moalimen & 7.56 & 2.16 & 385 & 156 & 8.99 & 190 & 235 & 70 & 272 & 370 & 0.35 & 0.40 & 0.70 \\
\hline 34 & Mosalth El Sadre & 7.75 & 0.54 & 447 & 150 & 14 & 130 & 198 & 35 & 130 & 230 & 0.02 & 0.60 & 1.00 \\
\hline 35 & Almatea El Qdima & 8.1 & 0.72 & 161 & 78 & 7.82 & 186 & 166.00 & 10 & 312 & 170 & 0.45 & 0.30 & 0.70 \\
\hline 36 & El Matea El Gadida & 7.85 & 1.93 & 233 & 110 & 9.78 & 110 & 96.00 & 20 & 119 & 306 & 0.08 & 0.23 & 0.18 \\
\hline 37 & El Nmaysa & 7.46 & 2.22 & 175 & 120 & 20.72 & 110 & 94.00 & 32 & 230 & 230 & 0.50 & 0.20 & 0.06 \\
\hline 38 & Shotb & 7.55 & 2.29 & 289 & 192 & 14.90 & 158 & 112.00 & 44 & 145 & 296 & 0.30 & 1.00 & 0.50 \\
\hline 39 & Mosha Qadima & 7.73 & 2.73 & 408 & 130 & 10.95 & 172 & 168.00 & 50 & 90 & 360 & 0.42 & 0.20 & 0.80 \\
\hline 40 & Refa El Qudema & 7.47 & 4.73 & 851 & 200 & 9.38 & 400 & 194.00 & 45 & 190 & 394 & 0.50 & 0.27 & 0.40 \\
\hline 41 & Der Dronka & 7.55 & 0.34 & 546 & 134 & 5.17 & 190 & 356 & 52 & 81 & 280 & 0.08 & 0.30 & 0.10 \\
\hline 42 & Mosha Gadida & 7.65 & 1.81 & 474 & 180 & 3.74 & 230 & 122 & 60 & 95 & 330 & 0.40 & 0.05 & 0.66 \\
\hline 43 & El Sheke Frge & 7.32 & 14.80 & 590 & 110 & 3.91 & 224 & 180 & 63 & 104 & 306 & 1.00 & 0.15 & 0.30 \\
\hline
\end{tabular}


Table 4 Results of chemical analyses of studied groundwater samples in Assuit Governorate (Continued)

\begin{tabular}{|c|c|c|c|c|c|c|c|c|c|c|c|c|c|c|}
\hline \multirow[t]{2}{*}{ N } & \multirow[t]{2}{*}{ Location } & \multirow[t]{2}{*}{$\mathrm{pH}$} & \multirow[t]{2}{*}{ Turb } & \multirow[t]{2}{*}{ TDS } & \multicolumn{4}{|c|}{ Major cation } & \multicolumn{3}{|c|}{ Major anion } & \multicolumn{3}{|c|}{ Trace Elements } \\
\hline & & & & & $\overline{\mathrm{Na}^{+}}$ & $\mathrm{K}^{+}$ & $\mathrm{Ca}^{+2}$ & $\mathrm{Mg}^{+}$ & $\overline{\mathrm{SO}_{4}{ }^{-2}}$ & $\mathrm{Cl}-$ & $\overline{\mathrm{HCO}_{3}}$ & $\overline{\mathrm{Fe}+}$ & $\mathrm{Mn+}$ & $\mathrm{NH}_{3}{ }^{-}$ \\
\hline 44 & El Gadrefy & 7.64 & 11.10 & 318 & 230 & 10.35 & 100 & 350 & 30 & 120 & 276 & 0.95 & 0.10 & 0.14 \\
\hline 45 & Masra & 7.42 & 1.45 & 194 & 90 & 11.17 & 112 & 55 & 19 & 317 & 230 & 0.05 & 0.13 & 0.10 \\
\hline 46 & Nage Sabe & 7.42 & 8.23 & 935 & 145 & 3.91 & 202 & 160 & 42 & 243 & 390 & 0.58 & 0.10 & 0.54 \\
\hline 47 & Nage AbdEl Rasule & 7.46 & 4.10 & 671 & 112 & 4.74 & 196 & 260 & 30 & 234 & 344 & 0.10 & 0.15 & 0.04 \\
\hline 48 & Qurqares & 7.41 & 6.10 & 376 & 90 & 3.91 & 156 & 280 & 58 & 158 & 396 & 0.58 & 0.20 & 0.34 \\
\hline 49 & Bany Hesine & 7.51 & 1.41 & 140 & 205 & 5.35 & 270 & 40 & 14 & 214 & 160 & 0.18 & 0.60 & 0.16 \\
\hline 50 & Bahege & 7.60 & 3.56 & 327 & 109 & 12.69 & 148 & 60 & 25 & 225 & 364 & 0.35 & 0.15 & 0.50 \\
\hline 51 & El Boraand Hedaya & 7.50 & 7.07 & 484 & 192 & 13.69 & 274 & 56.00 & 26 & 487 & 324 & 0.42 & 0.20 & 0.02 \\
\hline 52 & El Gazira Sahel Salime & 7.60 & 6.80 & 694 & 180 & 3.91 & 315 & 135.00 & 29 & 170 & 390 & 1.70 & 0.24 & 0.49 \\
\hline 53 & Buate & 7.37 & 6.56 & 621 & 155 & 3.91 & 315 & 135.00 & 36 & 140 & 610 & 0.77 & 0.25 & 0.72 \\
\hline 54 & El Mahata El Morasha & 8.62 & 10 & 180 & 280 & 12.74 & 119 & 51.00 & 16 & 116 & 150 & 0.77 & 0.10 & 0.59 \\
\hline 55 & Der Tasa & 7.63 & 1.53 & 1111 & 233 & 14.86 & 336 & 144.00 & 44 & 490 & 400 & 1.20 & 0.21 & 0.10 \\
\hline 56 & El Nazla El Mostgda & 7.66 & 1.41 & 659 & 156 & 11.73 & 308 & 132.00 & 32 & 333 & 420 & 1.27 & 0.16 & 0.10 \\
\hline 57 & El Matmer El Gaded & 7.80 & 1.07 & 768 & 150 & 12.04 & 238 & 102.00 & 63 & 195 & 174 & 1.30 & 0.10 & 0.10 \\
\hline 58 & Awna & 7.70 & 1.38 & 467 & 78 & 6.26 & 287 & 123.00 & 11 & 227 & 300 & 2.10 & 0.40 & 0.35 \\
\hline 59 & El Matmer El Qudeme & 7.70 & 0.38 & 1700 & 110 & 10.33 & 494 & 211.00 & 10 & 542 & 240 & 1.76 & 0.10 & 0.10 \\
\hline 60 & Arab Moter El Matmer & 7.59 & 0.52 & 900 & 120 & 7.04 & 224 & 96.00 & 22 & 270 & 280 & 0.72 & 0.20 & 0.46 \\
\hline 61 & El Habaysha & 7.75 & 2.52 & 457 & 116 & 13.29 & 116 & 49.00 & 30 & 103 & 250 & 1.10 & 0.10 & 0.22 \\
\hline 62 & Abnob E IQudema & 7.40 & 0.98 & 433 & 110 & 8.99 & 110 & 102.00 & 38 & 50 & 260 & 0.10 & 0.20 & 0.36 \\
\hline 63 & Bani Mohammadeyat & 7.50 & 2.63 & 472 & 148 & 10.56 & 148 & 84.00 & 45 & 75 & 180 & 0.30 & 0.30 & 1.95 \\
\hline 64 & Gzeret El Aakb & 7.40 & 2.76 & 513 & 203 & 8.02 & 236 & 168.00 & 50 & 245 & 370 & 0.40 & 0.30 & 1.55 \\
\hline 65 & Koom Abo Sheel & 7.40 & 2.39 & 583 & 220 & 7.04 & 218 & 162.00 & 38 & 220 & 394 & 0.10 & 0.40 & 0.46 \\
\hline 66 & El Hamam & 7.40 & 0.82 & 565 & 255 & 7.82 & 248 & 192.00 & 10 & 60 & 344 & 0.10 & 0.30 & 0.33 \\
\hline 67 & Arab El Qdadehe & 7.60 & 22.60 & 431 & 142 & 7.82 & 156 & 150.00 & 15 & 221 & 256 & 0.60 & 0.30 & 0.39 \\
\hline 68 & Azbit Abd Alwahed & 7.30 & 1.14 & 604 & 200 & 11.73 & 210 & 120.00 & 35 & 435 & 324 & 0.30 & 0.00 & 1.68 \\
\hline 69 & Alkhatba & 7.20 & 1.01 & 270 & 95 & 5.50 & 390 & 138.00 & 28 & 220 & 180 & 0.30 & 0.00 & 0.88 \\
\hline 70 & Bani Abriham & 7.40 & 3.10 & 610 & 200 & 12.51 & 200 & 160.00 & 38 & 128 & 330 & 0.40 & 0.40 & 0.77 \\
\hline 71 & El khlayfa & 7.50 & 1.20 & 374 & 350 & 7.04 & 136 & 100.00 & 15 & 118 & 240 & 0.50 & 0.30 & 1.12 \\
\hline 72 & Al Hawy & 7.30 & 5.00 & 380 & 142 & 8.21 & 140 & 60.00 & 25 & 228 & 170 & 0.40 & 0.20 & 0.28 \\
\hline 73 & Abo Emera & 7.40 & 3.62 & 461 & 156 & 8.21 & 164 & 96.00 & 60 & 324 & 280 & 0.40 & 0.20 & 0.01 \\
\hline 74 & DerShow & 7.40 & 3.60 & 345 & 133 & 9.78 & 128 & 86.00 & 30 & 125 & 230 & 0.40 & 0.20 & 0.05 \\
\hline 75 & El Mash & 7.40 & 1.30 & 411 & 166 & 10.80 & 160 & 70.00 & 25 & 130 & 260 & 0.30 & 0.30 & 0.60 \\
\hline 76 & El Bdary El Garbya & 7.23 & 3.65 & 507 & 280 & 5.08 & 281 & 120.00 & 51 & 51 & 242 & 1.59 & 1.00 & 0.05 \\
\hline 77 & Nazlit El Khntera & 7.32 & 2.31 & 652 & 225 & 15.00 & 250 & 108.00 & 57 & 55 & 265 & 1.62 & 0.67 & 1.72 \\
\hline 78 & El talot & 7.53 & 4.76 & 767 & 255 & 10.95 & 250 & 106.00 & 36 & 130 & 369 & 1.30 & 0.51 & 0.53 \\
\hline 79 & El Atmanya & 7.58 & 0.90 & 1177 & 320 & 8.99 & 315 & 135.00 & 48 & 390 & 275 & 1.26 & 0.10 & 0.31 \\
\hline 80 & Nage El Maidy & 7.58 & 3.59 & 928 & 329 & 10.55 & 329 & 141.00 & 65 & 250 & 270 & 1.64 & 0.83 & 0.41 \\
\hline 81 & Monsh Hamam & 7.50 & 4.40 & 396 & 250 & 7.82 & 254 & 109.00 & 30 & 130 & 389 & 2.02 & 0.49 & 0.10 \\
\hline 82 & El Akale El Kably & 7.21 & 4.92 & 645 & 280 & 9.78 & 273 & 117.00 & 16 & 110 & 140 & 2.35 & 0.56 & 0.10 \\
\hline 83 & El Hamamya & 7.82 & 5.24 & 754 & 248 & 12.72 & 245 & 105.00 & 12 & 110 & 110 & 2.00 & 0.68 & 0.24 \\
\hline 84 & Mahmod Farge & 7.64 & 1.21 & 880 & 296 & 13.80 & 299 & 128.00 & 23 & 230 & 250 & 2.00 & 0.10 & 0.10 \\
\hline 85 & El Nwawra & 7.50 & 0.38 & 448 & 210 & 10.95 & 215 & 92.00 & 51 & 77 & 264 & 2.00 & 0.10 & 0.10 \\
\hline 86 & El Bdary El Shrkya & 7.31 & 303.00 & 517 & 230 & 9.38 & 252 & 108.00 & 50 & 50 & 224 & 1.80 & 0.49 & 0.30 \\
\hline
\end{tabular}


Table 4 Results of chemical analyses of studied groundwater samples in Assuit Governorate (Continued)

\begin{tabular}{|c|c|c|c|c|c|c|c|c|c|c|c|c|c|c|}
\hline \multirow[t]{2}{*}{$\bar{N}$} & \multirow[t]{2}{*}{ Location } & \multirow[t]{2}{*}{$\mathrm{pH}$} & \multirow[t]{2}{*}{ Turb } & \multirow[t]{2}{*}{ TDS } & \multicolumn{4}{|c|}{ Major cation } & \multicolumn{3}{|c|}{ Major anion } & \multicolumn{3}{|c|}{ Trace Elements } \\
\hline & & & & & $\overline{\mathrm{Na}^{+}}$ & $\mathrm{K}^{+}$ & $\mathrm{Ca}^{+2}$ & $\mathrm{Mg}^{+}$ & $\mathrm{SO}_{4}^{-2}$ & $\mathrm{Cl}-$ & $\mathrm{HCO}_{3}$ & $\overline{\mathrm{Fe}+}$ & $\mathrm{Mn+}$ & $\mathrm{NH}_{3}$ \\
\hline 87 & El Kome El Ahmer & 7.62 & 0.66 & 636 & 188 & 11.17 & 172 & 73.00 & 22 & 184 & 258 & 0.34 & 0.10 & 0.66 \\
\hline 88 & Wady Shehe & 7.60 & 0.70 & 1051 & 270 & 12.74 & 260 & 111.00 & 25 & 350 & 260 & 1.50 & 0.10 & 0.28 \\
\hline 89 & Kome Saide El Garpy & 7.50 & 6.98 & 1170 & 310 & 13.91 & 500 & 294.00 & 29 & 240 & 340 & 0.60 & 0.60 & 0.05 \\
\hline 90 & kome saide & 7.30 & 1.11 & 365 & 150 & 12.35 & 160 & 120.00 & 45 & 60 & 314 & 0.05 & 0.30 & 0.10 \\
\hline 91 & El Beba & 7.90 & 1.20 & 233 & 160 & 11.17 & 170 & 70.00 & 45 & 236 & 254 & 0.30 & 0.05 & 0.10 \\
\hline 92 & El Gnayem El Shirke & 7.50 & 2.20 & 312 & 180 & 13.91 & 190 & 40 & 24 & 124 & 362 & 0.40 & 0.25 & 0.05 \\
\hline
\end{tabular}
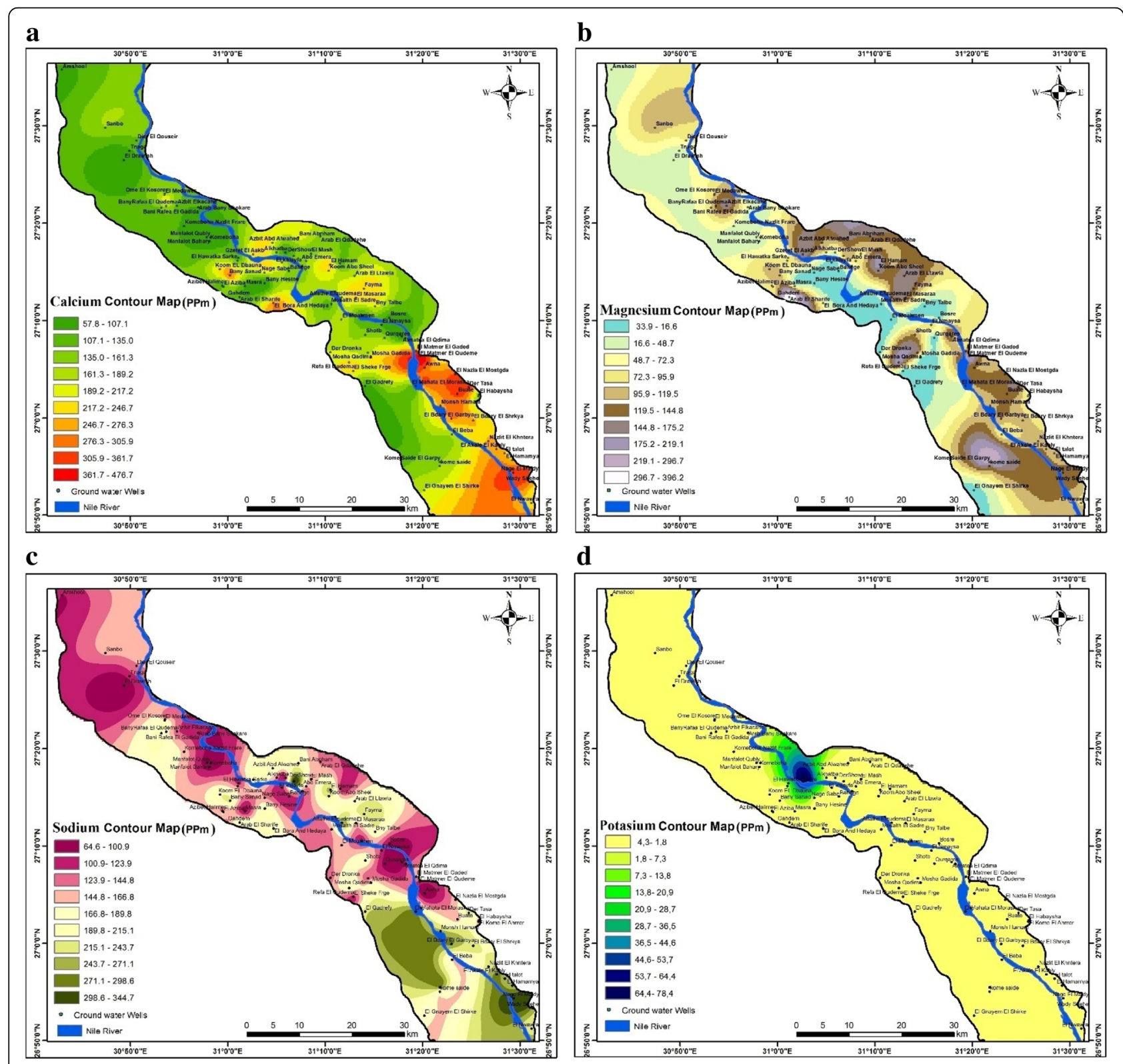

Fig. 8 Iso-concentration maps showing spatial variation in a $\mathrm{Ca}$, b $\mathrm{Mg}, \mathbf{c ~ N a}$, and $\mathbf{d} \mathrm{K}$ in the study area (values in milligrams per liter) 
increase in the calcium at the southwest parts of study area. Calcium concentration decrease near the Nile River. The accepted limit of calcium value for drinking water according to Egyptian standards is $200 \mathrm{ppm}$. Which means that the calcium concentration in the groundwater in the area is acceptable for western Sedfa and southwest of Assiut areas (Fig. 9a).

The sodium content in the groundwater samples range from 78 to $329 \mathrm{ppm}$. The maximum recommended World Health Organization limit for Na concentration in drinking water is $200 \mathrm{ppm}$. More lower $\mathrm{Na}$ concentration is recorded ( 3.5 to $15 \mathrm{ppm}$ ) in all of the analyzed samples (Fig. 8b). This result indicates that all the wells in the studied area contain water having $\mathrm{Na}$ content acceptable according to the World Health Organization limit $(200 \mathrm{mg} / \mathrm{L})$ for domestic use (Fig. 9b).

The values of magnesium in groundwater samples ranged from 40 to $300 \mathrm{ppm}$. Figure $8 \mathrm{c}$ and Table 4 show an increase in magnesium east of Abnoub. Magnesium concentration generally decreases in the southern parts of study area. It decreases near the River Nile and EL-Ibrahimiya Canal. The accepted limit of magnesium value in drinking water according to Egyptian standards

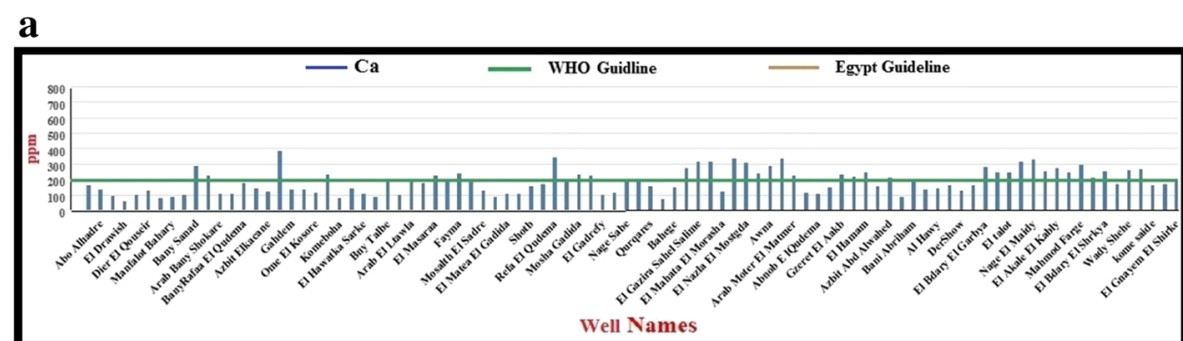

b

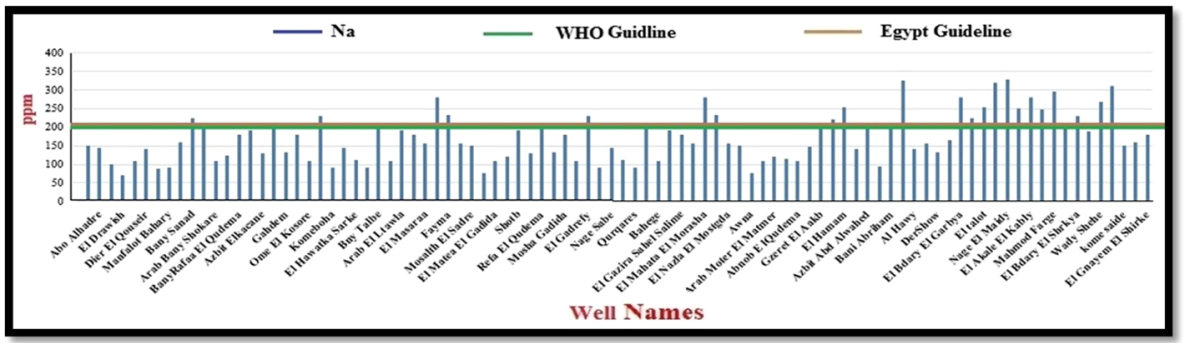

c

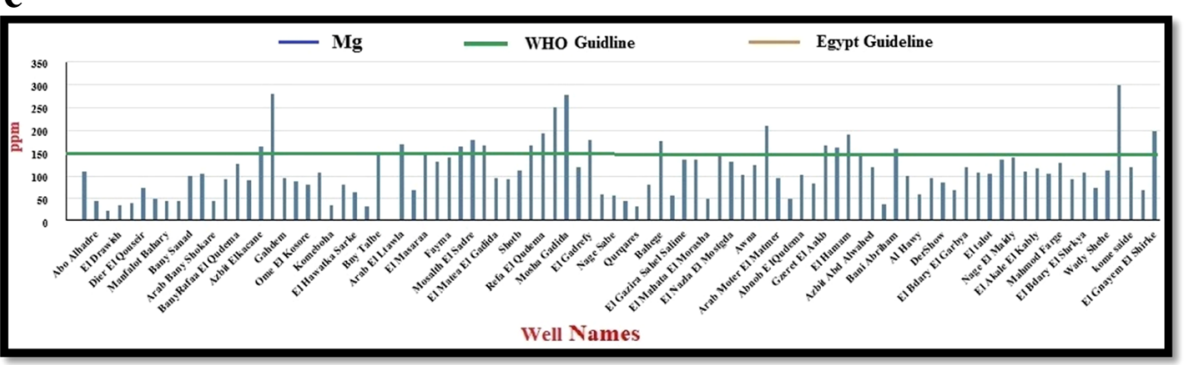

d

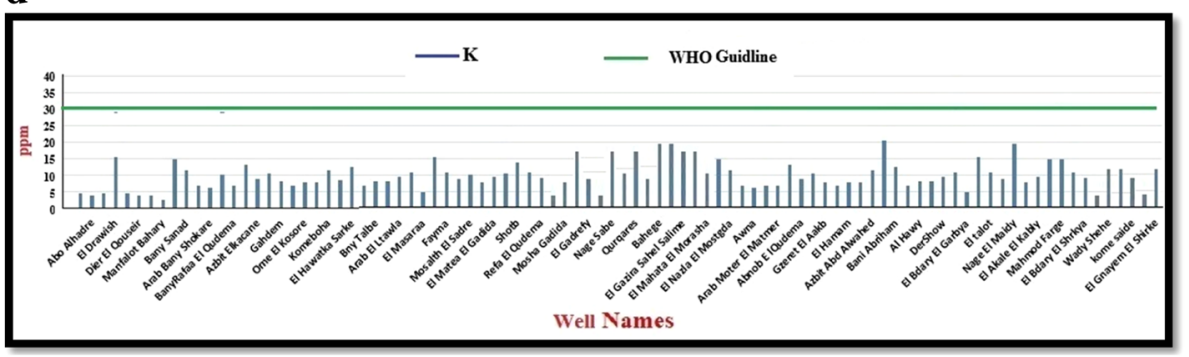

Fig. 9 a Ca, b Mg, c Na, and $\mathbf{d} \mathrm{K}$ concentration of groundwater samples compared with WHO Guidelines (2004) and Egyptian Higher Committee for Water (2007) guidelines for drinking water 
is $150 \mathrm{ppm}$. So, the groundwater in the area is acceptable for drinking purposes except for that in northwestern part of Assiut city and north Abnoub (Fig. 9c).

The chloride content in groundwater samples ranged from 50 to $550 \mathrm{ppm}$. Figure 10a and Table 4 shows an increase in the chloride content between the western part of Manfalout and Assiut. The maximum acceptable limit of chloride value for drinking water according to the Egyptian and WHO Standards is $250 \mathrm{ppm}$. So the groundwater in the area is acceptable for drinking purposes except for the western part between Manfalout and Assiut City (Fig. 11a).
Few local areas show relatively high bicarbonate content (Fig. 10b), especially in the northern zone and at the desert fringes because of the dissolution of the carbonates from the adjacent carbonate rocks (Fig. 11b).

Sulfate content ranges from 10 to $70 \mathrm{ppm}$ in the study area (Fig. 10c). The sulfate content is also locally high at the western part because of the extension of the Miocene sediments containing gypseous limestone. Low content of sulfate ions is observed in the northern and eastern parts of the area. This may be due to seepage of freshwater from the River Nile and El-Ibrahimyya canal (Fig. 11c).

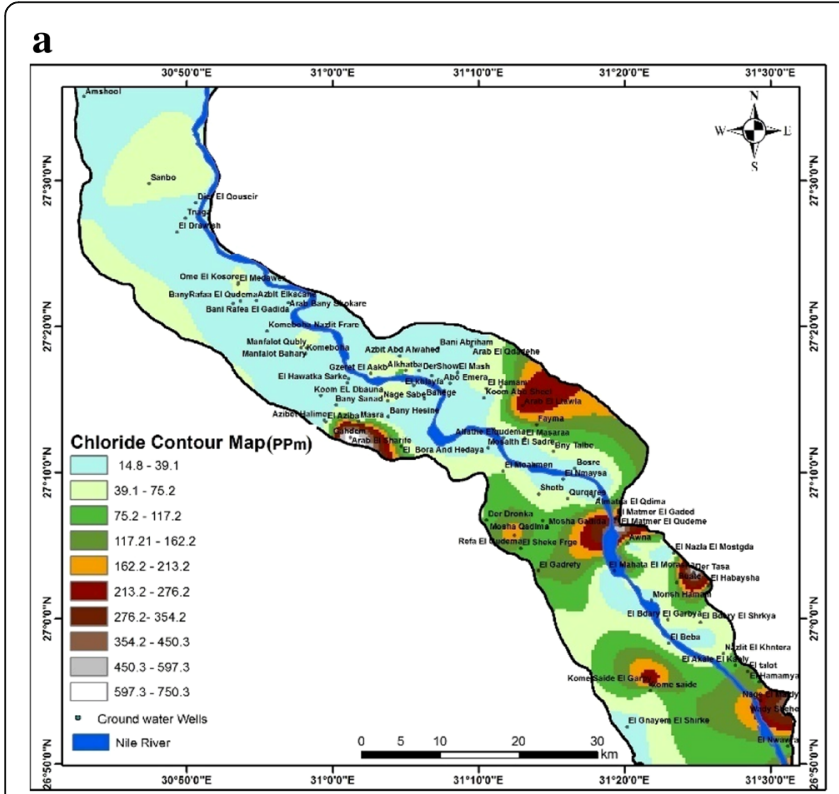

\section{b}

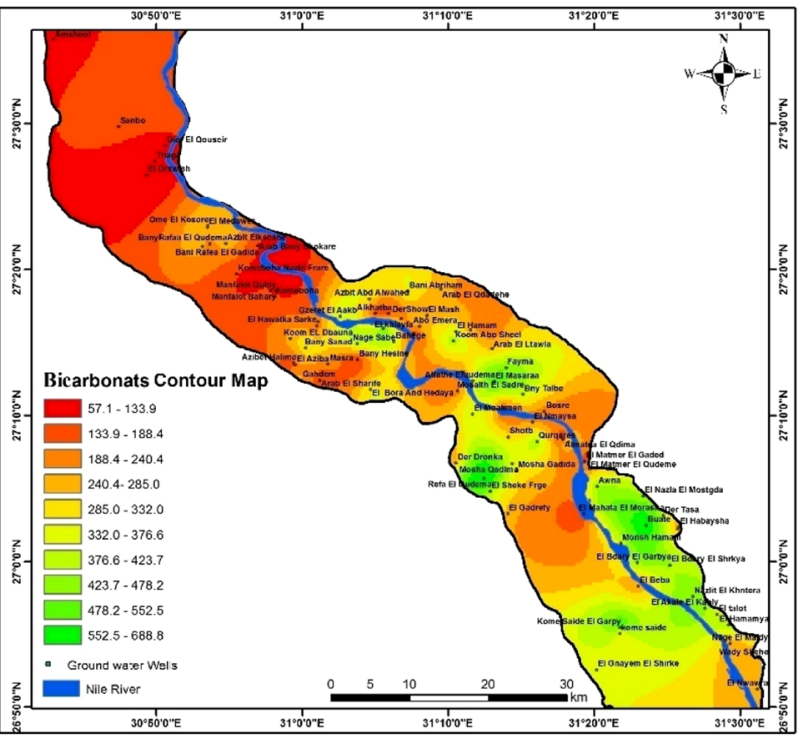

c

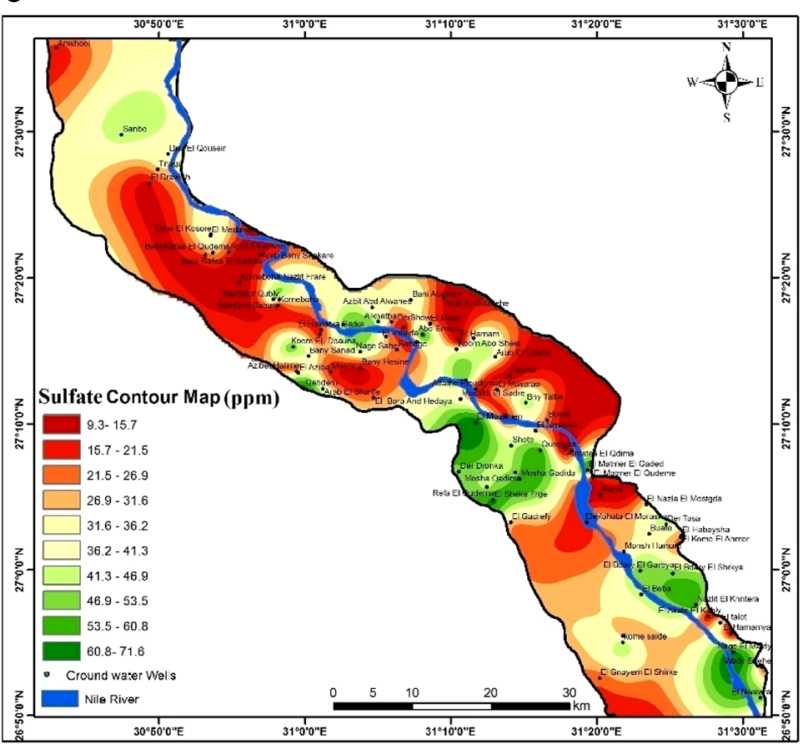

Fig. 10 Iso-concentration maps showing spatial variation in $\mathbf{a} \mathrm{Cl}, \mathbf{b} \mathrm{HCO}_{3}$, and $\mathbf{c} \mathrm{SO}_{4}$ in the study area (values in milligrams per liter) 


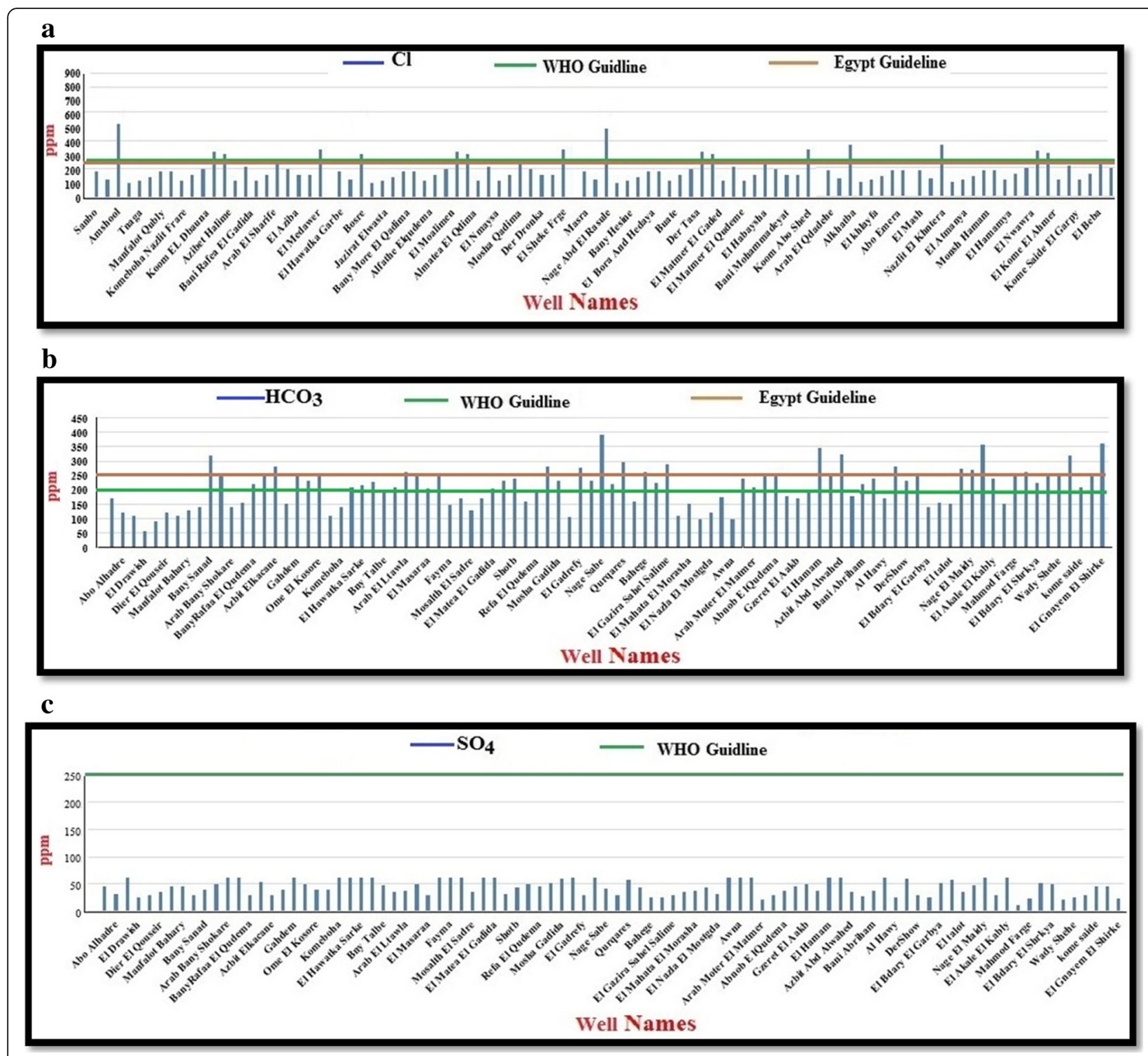

Fig. 11 a Cl, b $\mathrm{HCO}_{3}$, and $\mathbf{c ~ S O}{ }_{4}$ concentration of groundwater samples compared with WHO Guidelines (2004) and Egyptian Higher Committee for Water (2007) guidelines for drinking water

Iron concentration in the groundwater in the area ranged from 0.1 to $1.6 \mathrm{ppm}$. Figure $12 \mathrm{a}$ and Table 4 show increases in iron content at southwestern parts of the area. The accepted limit of iron for drinking water according to the Egyptian standards is 0.3 ppm (Fig. 13a).

The values of manganese in groundwater in the area ranged from 0.1 to $1 \mathrm{ppm}$. Figure $12 \mathrm{~b}$ shows a slightly increase in the manganese concentration in the area at the southern part of the area, especially between Assuit and Abo Tieg. The accepted limit of manganese value for drinking water according to the Egyptian and WHO is 0.4 ppm. Only in Sedfa area and in south Assiut localities more manganese content then the recommended limits (Fig. 13b).
The values of ammonia content in groundwater ranged from 0 to $1.4 \mathrm{ppm}$. Local increase in the ammonia values at the eastern parts of study area between Qusiya and Manfalout are observed (Fig. 12a). The accepted limit of ammonia value for drinking water according to Egyptian standards is $0.5 \mathrm{ppm}$, so the groundwater in the area can be accepted for drinking purposes except for that of Dayrout and in the area between Qusiya and Manfalout.

\section{Bacteriological analysis results}

A total of 2189 groundwater samples were collected from 92 groundwater wells distributed in Assiut 


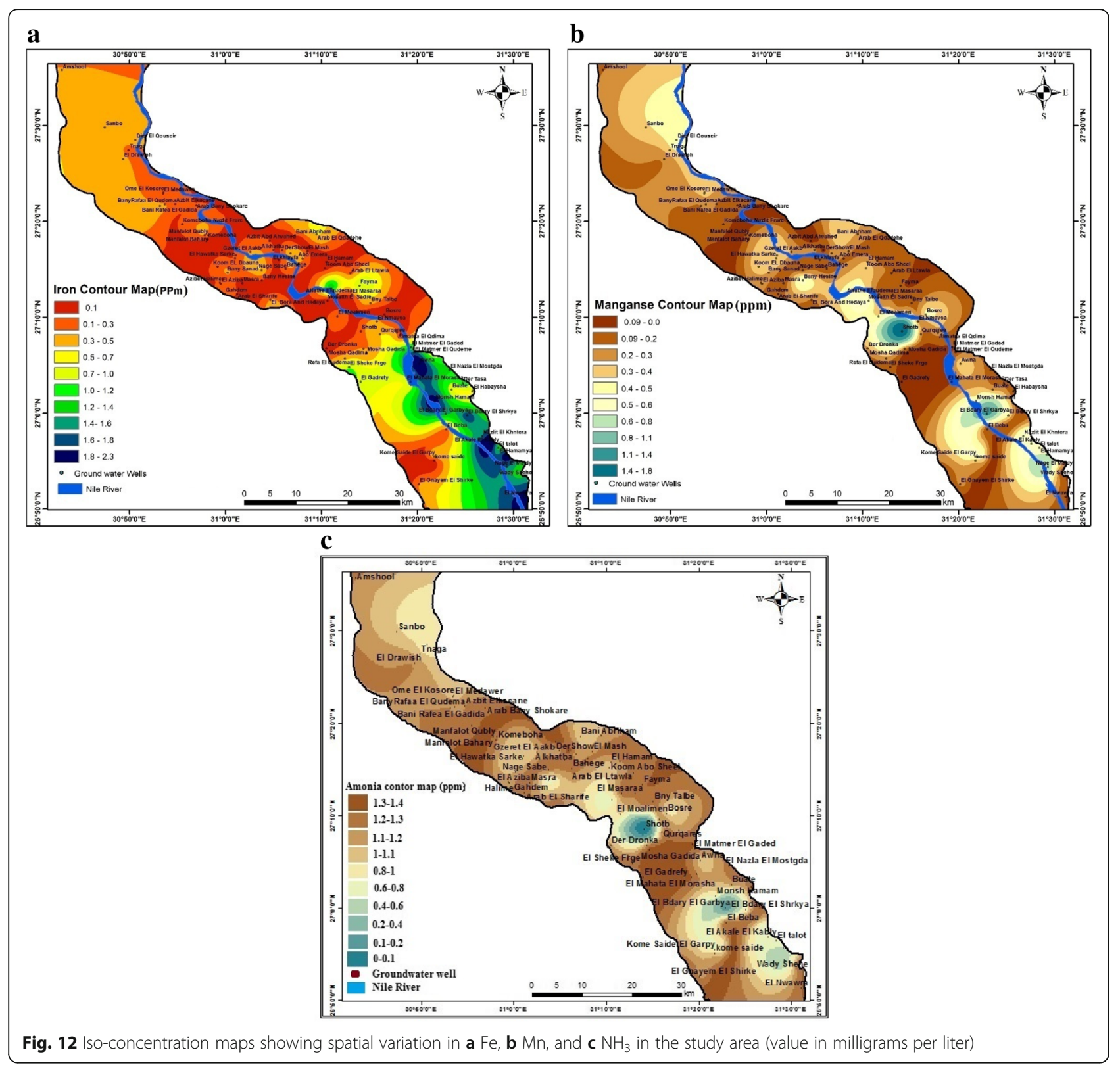

Governorate during the period between January and November 2017 (Table 5). The samples were examined for total coliform and analyzed in the laboratories of the applied Bacteriology, Botany and Microbiology Department, Faculty of Science, Assiut University and in the Holding company for drinking and waste water, (Assiut Drinking and Sanitation Company).

The results of bacteriological examination are shown in Fig. 14. Data show that the highest probable number of total coliform was found to be $5.9 \mathrm{MPN} / 100 \mathrm{ml}$ and the minimum value of MPN of total coliform was found to be $1.1 \mathrm{MPN} / 100 \mathrm{ml}$.
The distribution of the total coliform in the groundwater in the area during the winter season is shown in Table 6 and Fig. 15a. The highest mean value of MPN/100 ml was founded in Abnob district followed by Assiut and Manfalut districts then El Badary and Sidfa, whereas the lowest mean values was found in Dayrout city followed by El Qusiya and Sahel Salime district.

In the spring period, the distribution of the total coliform is shown in (Table 6 and Fig. 15b). The highest mean value of MPN/100 ml was found in Abo Tegi and Abnob cities followed by El fath and Assiut district then Manfalut and El Badary, whereas the lowest mean values were found in El Qusiya and Sahel Salime district. 


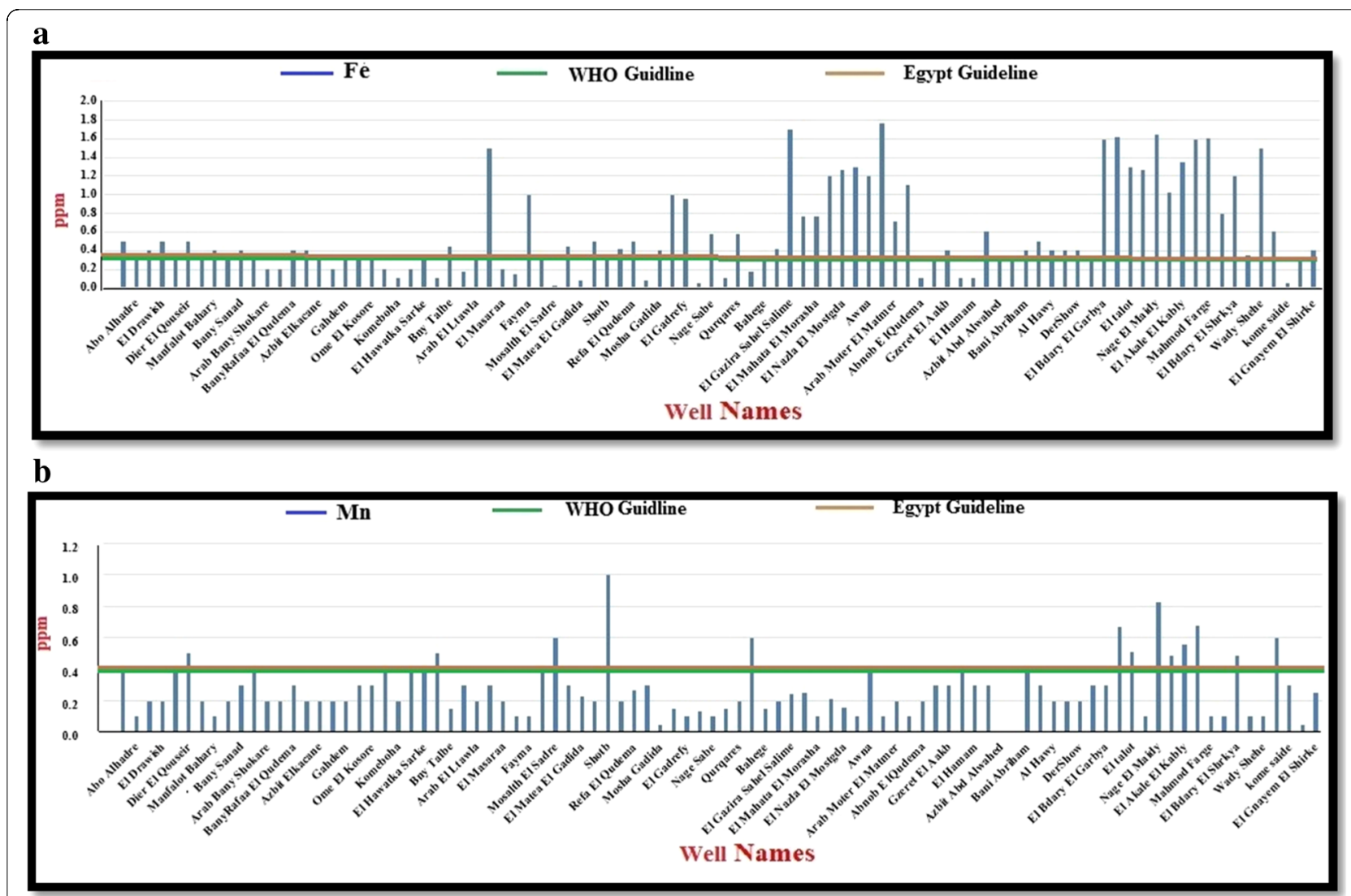

Fig. 13 a Fe and $\mathbf{b}$ Mn concentration of groundwater samples compared with WHO Guidelines (2004) and Egyptian Higher Committee for Water (2007) guidelines for drinking water

In the summer period, the distribution of the mean value of total coliform is shown in Table 6 and Fig. 15c. The highest mean values of MPN/100 ml was found in El Badary, Assiut, El fath, and Abnob district then Manfalut and El Gnayem, whereas the lowest mean values of MPN/100 $\mathrm{ml}$ was found in $\mathrm{El}$ Qusiya and Dayrout district.

In the autumn period, the distribution of the mean value of total coliform in the study area is shown in Table 6 and Fig. 15d. The highest mean values of were

Table 5 Total coliform averages (MPN/100 ml) (2017)

\begin{tabular}{|c|c|c|c|c|c|c|c|c|c|c|c|c|}
\hline & Dayrout & Qusiya & Manfalot & Abnob & Elfathe & Asuit City & Asuit & Abo Tegi & Sahel Salime & Bdary & Sidfa & Ghanayem \\
\hline January & 1.89478 & 1.2426 & 1.7032 & 3.9525 & 2.859 & 1.7 & 2.7682 & 1.95833 & 1.1 & 3.3808 & 1.6996 & 1.5976 \\
\hline February & 1.1 & 1.1068 & 3.32745 & 3.325 & 1.4106 & 1.1 & 2.3128 & 1.7121 & 1.1 & 1.4521 & 3.0867 & 2.2428 \\
\hline March & 1.7604 & 1.4374 & 1.8533 & 4.07962 & 1.909 & 1.1 & 2.5608 & 3.4347 & 1.3075 & 1.2557 & 3.0958 & 2.5583 \\
\hline April & 2.0933 & 1.9636 & 2.4032 & 3.3226 & 2.9166 & 1.1 & 1.20138 & 3.7255 & 1.13666 & 1.5173 & 1.1 & 1.1 \\
\hline May & 1.8256 & 1.47272 & 2.1071 & 4.29561 & 2.3635 & 1.1 & 2.8578 & 5.2666 & 3.29 & 3.25166 & 1.1 & 1.1 \\
\hline June & 1.3428 & 1.5955 & 2.35478 & 2.2488 & 2.271 & 2.795 & 2.18333 & 4.85 & 1.7866 & 4.1555 & 2.8888 & 3.8828 \\
\hline July & 1.1 & 1.40982 & 2.1906 & 3.4755 & 4.5054 & 1.1 & 5.065 & 1.1 & 1.333 & 5.7653 & 1.1 & 1.1 \\
\hline August & 1.5674 & 1.5242 & 1.43206 & 4.1566 & 2.9826 & 1.775 & 2.5931 & 1.12036 & 1.465 & 1.3 & 1.1 & 1.1 \\
\hline September & 1.4222 & 1.3152 & 2.5032 & 2.9523 & 1.4625 & 3.8375 & 5.478 & 1.2885 & 1.3 & 1.1 & 1.75 & 1.1 \\
\hline October & 1.4611 & 1.18888 & 2.56 & 1.1 & 1.1 & 1.1 & 1.1 & 1.1 & 1.1 & 3.8375 & 1.1 & 1.1 \\
\hline November & 1.5264 & 1.187 & 1.1 & 1.1 & 1.1 & 1.1 & 1.1 & 1.1 & 1.2466 & 2.5166 & 1.1 & 1.1 \\
\hline
\end{tabular}




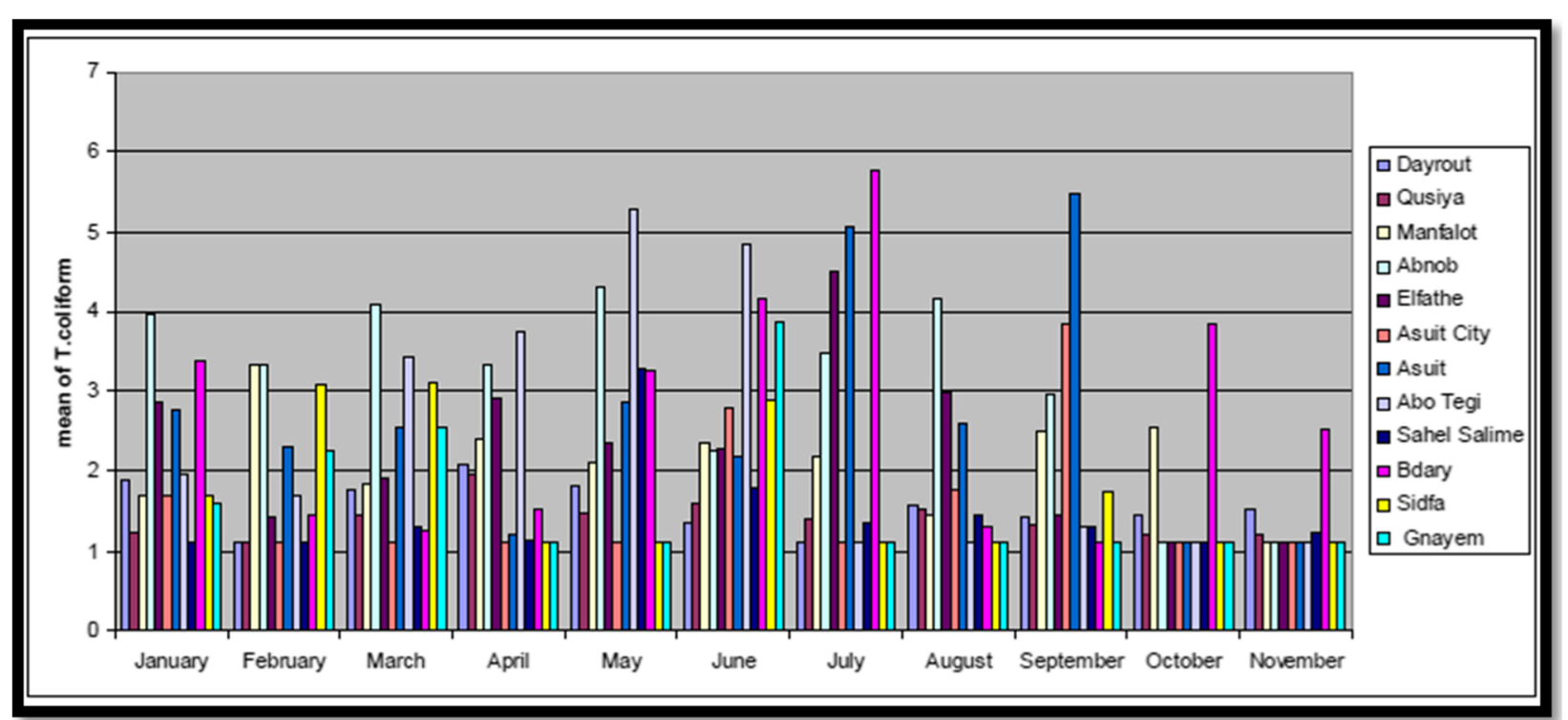

Fig. 14 Mean values of total coliform in the study area from Jan 2017 to Nov 2017

founded in El Badary, Assiut, El fath, and Abnob district then Manfalut and Gnayem, whereas the lowest values were found in Qusiya and Dayrout district.

\section{Discussion}

\section{Water resource potentiality model for drinking uses} Water potentiality spatial model

The study developed water potentiality spatial model to identify the most appropriate area for drinking uses planning based on the bacteriological and chemical analysis; the model input included nine variables, i.e., water salinity, wells depth, and chemical and physical analysis of minor and major of groundwater wells. The results of the model are classified into five potentiality classes, such as high, moderately high, moderate, moderately low, and low. Figure 16 shows the model structure. Inspection of the model output (Fig. 17) indicates that the high quality of the groundwater of the quaternary aquifer is located in north of the Manfalut city, and two local lenses in south in ElFath and Abo Tig area. While low quality of groundwater is concentrated in the southern part of Assuit Governorate.

\section{Conclusions}

The study revealed that most of the groundwater in the area is suitable for drinking purposes according to

Table 6 Total seasonal coliform (MPN/100 ml) (2017)

\begin{tabular}{lllll}
\hline & Winter & Spring & Summer & Autumn \\
\hline Dayrout & 1.49739 & 1.8931 & 1.336733 & 1.4699 \\
Qusiya & 1.1747 & 1.62457 & 1.50984 & 1.4636 \\
Manfalot & 2.515325 & 2.1212 & 1.99248 & 2.5316 \\
Abnob & 3.63875 & 3.89927 & 3.293633 & 2.02615 \\
Elfathe & 2.1348 & 2.396366 & 3.253 & 1.28125 \\
Asuit City & 1.4 & 1.1 & 1.89 & 2.46875 \\
Asuit & 2.5405 & 2.20666 & 3.28047 & 3.289 \\
Abo Tegi & 1.835215 & 4.142266 & 2.98518 & 1.19425 \\
Sahel Salime & 1.1 & 1.91138 & 1.5272 & 1.215533 \\
Bdary & 2.41645 & 2.0082 & 3.74026 & 2.4847 \\
Sidfa & 2.39315 & 1.765266 & 1.696 & 1.425 \\
Gnayem & 1.9202 & 1.5861 & 2.0276 & 1.1 \\
\hline
\end{tabular}



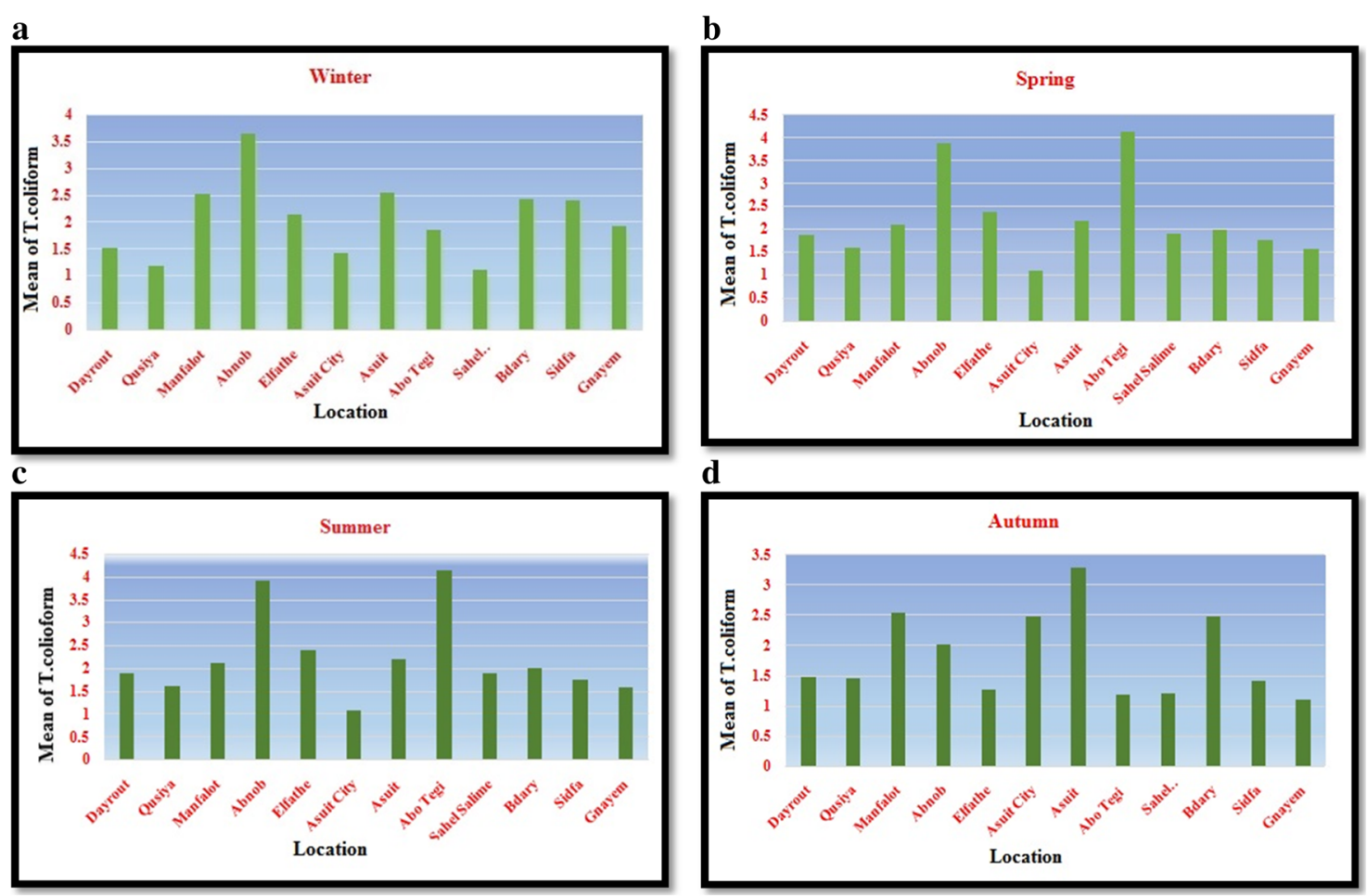

Fig. 15 Mean values of total coliform in the study area in a winter, b spring, c summer, and $\mathbf{d}$ autumn season from Jan 2017 to Nov 2017

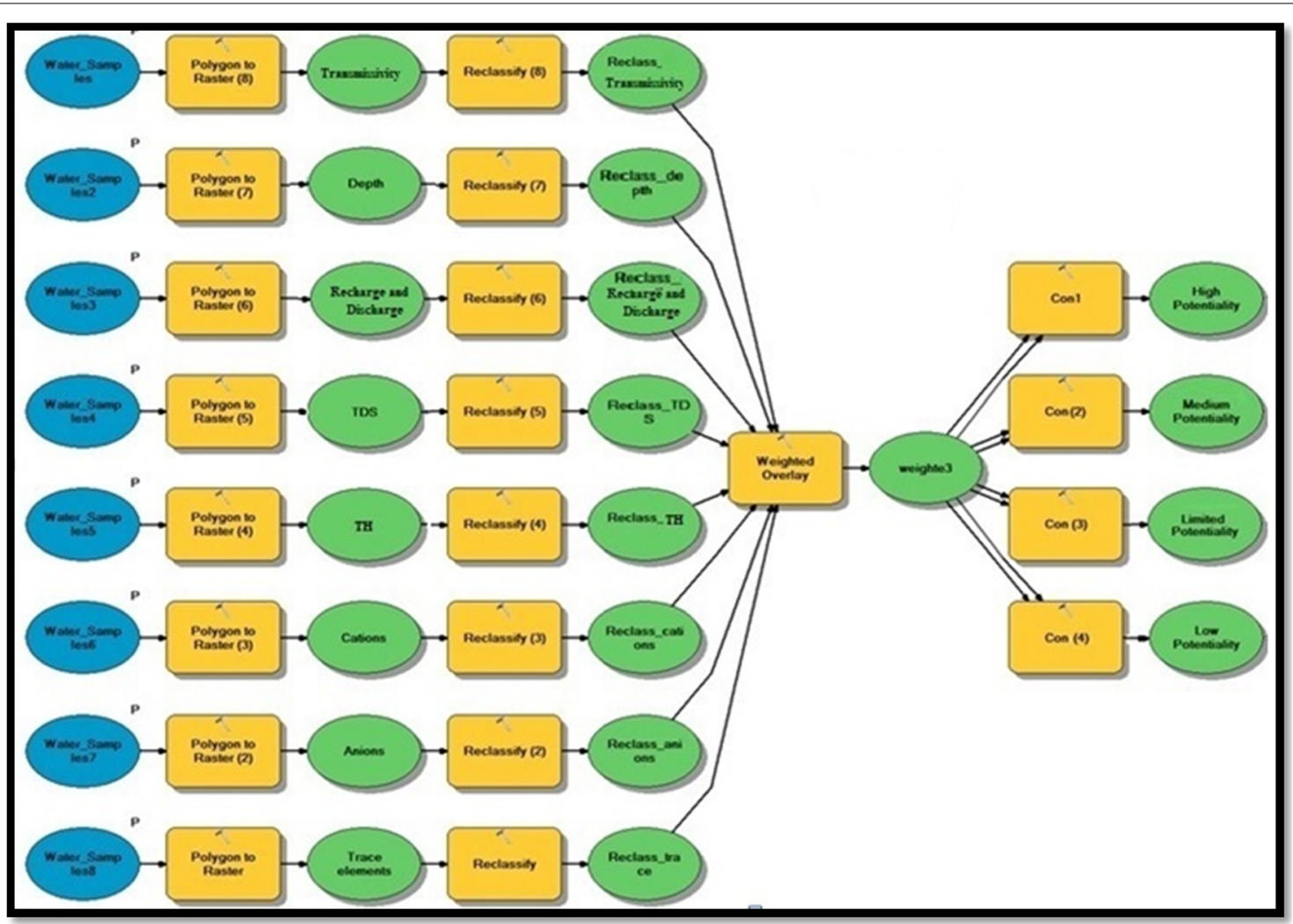

Fig. 16 Water recourses potentiality model flow chart for drinking uses 


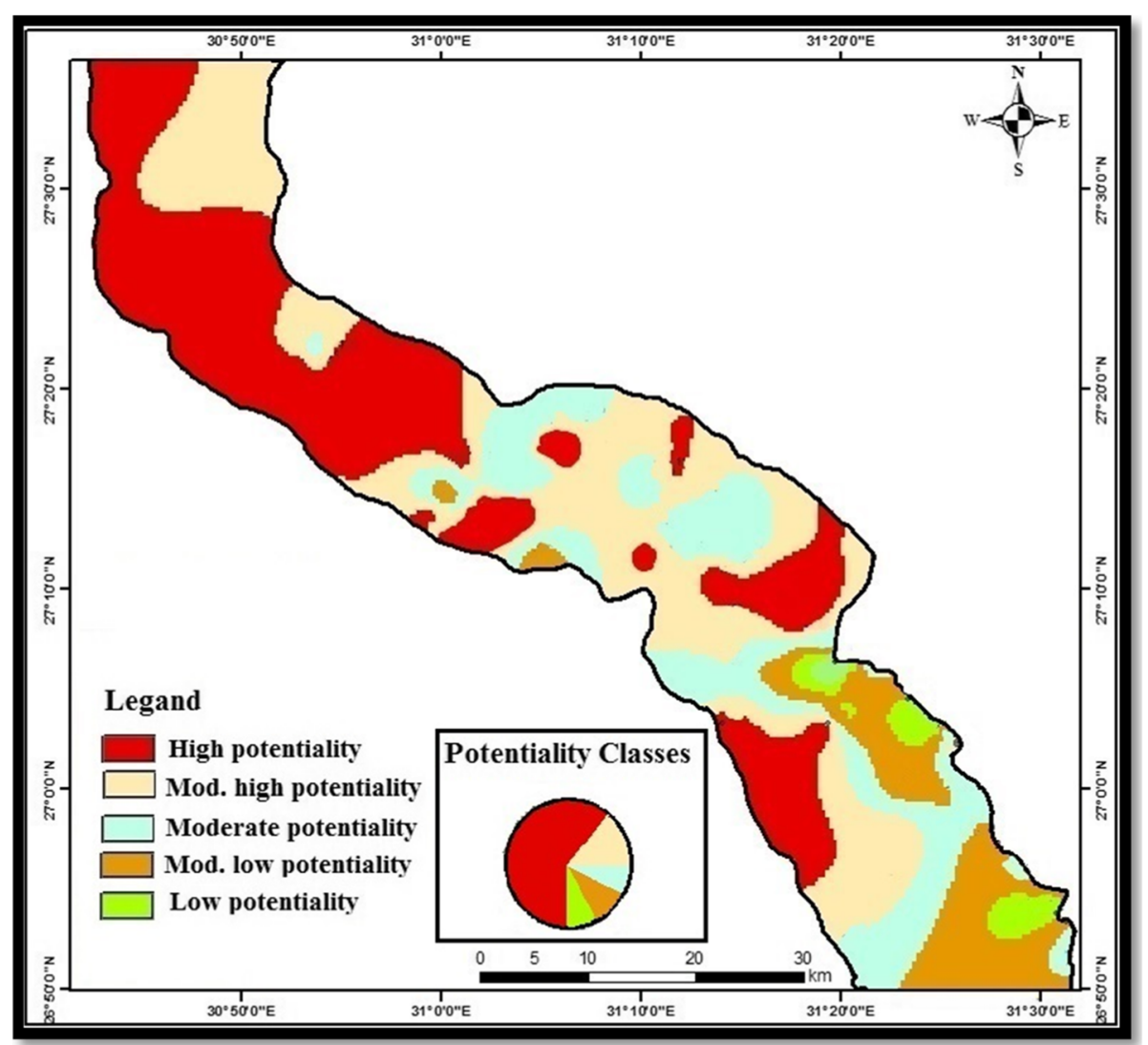

Fig. 17 Groundwater potentiality map of the study area for drinking uses

the chemical composition and the bacteriological analysis. The water quality is better close to the River Nile and El Ibrahymia Canal. Low water quality was detected close to the bounding of the Nile Valley either because of the effect of the adjacent Limestone plateau or the effect the Pliocene deposits.

\section{Abbreviations \\ $\mathrm{Ca}^{2+}$ : Calcium; $\mathrm{Cl}^{-}$: Chloride; EBT: Eriochrome Black T; Fe': Iron; GIS: Geographic information system; $\mathrm{HCO}_{3}{ }^{-}$: Bicarbonate; $\mathrm{K}^{+}$: Potassium; $\mathrm{Mg}^{2}$ ${ }^{+}$: Magnesium; $\mathrm{Mn}^{+}$: Manganese; MPN/100 ml: Most probable number per $100 \mathrm{ml}$; MTF: Multiple tube fermentation; MTF: Multiple-tube fermentation technique; $\mathrm{Na}^{+}$: Sodium; $\mathrm{NH}_{3}{ }^{-}$: Ammonia; $\mathrm{pH}$ : Hydrogen ion concentrations; $\mathrm{SO}_{4}{ }^{2-}$ : Sulfate; TC: Total coliform; TDS: Total dissolved solids; WHO: World Health Organization; WPSM: Water potentiality spatial model}

\section{Acknowledgements}

Not applicable

\section{Funding}

Not applicable

\section{Availability of data and materials}

All data generated or analyzed during this study are included in this manuscript.

\section{Authors' contributions}

HAM collected the groundwater samples and performed the chemical analyses of these samples and studied the geology and climate of the study area. AE-HAF build up the water potentiality spatial model to identify the most appropriate area for drinking uses planning based on the bacteriological and chemical analysis. Both authors read and approved the final manuscript.

\section{Authors' information}

Hanaa A. Megahd is a researcher in Hydrology, National Authority for Remote Sensing and Space Sciences.

Abd El-Hay A. Farrag is a professor of hydrology, Department of Geology, Faculty of Science, Assiut University.

Ethics approval and consent to participate

Not applicable

Consent for publication

Not applicable

Competing interests

The authors declare that they have no competing interests.

\section{Publisher's Note}

Springer Nature remains neutral with regard to jurisdictional claims in published maps and institutional affiliations.

\section{Author details}

${ }^{1}$ National Authority for Remote Sensing and Space Sciences (NARSS), Cairo, Egypt. ${ }^{2}$ Department of Geology, Faculty of Science, Assiut University, Assiut, Egypt. 
Received: 22 January 2019 Accepted: 12 March 2019

Published online: 25 March 2019

\section{References}

APHA (American Public Health Association)-AWWA (American Water Works Association) (1994) Standard methods for the examination of water and wastewater, 15th edn. American Public Health Association, Washington, DC

Egyptian Higher Committee for Water (2007) Egyptian standards for drinking and domestic uses. EHCW, Cairo

Evans TM, Waarvick CE, Seidler RJ, LeChevallier MW (1981) Failure of the mostprobable-number technique to detect coliforms in drinking water and raw water supplies. Appl Environ Microbiol 41:130-138

Farrage AA (1982) Hydrogeological studies on the quaternary water bearing sediments in the area between Assiut and Aswan. M.Sc. thesis, Faculty of Science, Assiut University

Farrage AA (1991) Hydrology of the Nile Basin between Assiut and Qena, Upper Egypt. Ph.D. thesis, Department of Hydrology and Engineering Geology, University of Prague, Czechoslovakia

Hem JD (1985) Study and interpretation of the chemical characteristics of natural water. United States Geol. Survey/Water Supply, Paper 2254. United States Geol. Survey, Washington DC

Macler AB, Merkel CJ (2000) Current knowledge on groundwater microbial pathogens and their control. Hydrogeol J 8:29-40

Mansour HH, Philobbos ER (1983) Lithostratigraphic classifications of the surface Eocene carbonates of the Nile Valley, Egypt. Bull Fac Sci Assiut Univ Assiut 12(2):129-153

Schijven JF, Hassanizadeh SM, Husman AMD (2010) Vulnerability of unconfined aquifers to virus contamination. Water Res 44(4):1170-1181

Seidler RJ, Evans TM, Kaufman, JR, Warvick CE, LeCheva-lier MW (1981) Limitations of standard coliform enumeration techniques. J. AWWA 73, 538-542.

WHO Guidelines (2004) "Water quality for ecosystem and human health", 2006 \& "global drinking water quality index development and sensitivity analysis report", 2007 Prepared and Published by the United Nations Environment Programme Global Environmental Monitoring System/Water Programme World Health Organization (1992) Our planet, our health, report of the WHO Commission on Health and Environment. World Health Organization, Geneva

\section{Submit your manuscript to a SpringerOpen ${ }^{\odot}$ journal and benefit from:}

- Convenient online submission

- Rigorous peer review

- Open access: articles freely available online

- High visibility within the field

- Retaining the copyright to your article

Submit your next manuscript at $\boldsymbol{\nabla}$ springeropen.com 